\title{
Risk (Predisposing) Factors for Non-Infectious Claw Disorders in Dairy Cows Under Varying Zero-Grazing Systems
}

\author{
J. Nguhiu-Mwangi, P.M.F. Mbithi, \\ J.K. Wabacha and P.G Mbuthia \\ Department of Clinical Studies, \\ Faculty of Veterinary Medicine, \\ University of Nairobi, \\ Kenya
}

\section{Introduction}

Lameness in cattle is one of the major causes of economic losses in dairy production systems (Hernandez et al., 2005; Kossaibati \& Esslemont, 1997). These losses occur through various negative impact directly on cattle and indirectly on the dairy production system. These include reduced milk yield (Hernandez et al., 2005), discarding of milk due to withdrawal period of drugs used to treat some of the lameness conditions, cost of veterinary drugs and professional services in managing the conditions (Enting et al., 1997), lowered conception rate and increased calving interval (Melendez et al., 2003; Sogstad et al.,2006), reduced ovarian activity during early postpartum period (Garbarino et al., 2004), as well as premature culling and occasional mortalities (Enting et al., 1997). Lameness has also been identified as a major welfare determinant in cattle because of discomfort and pain that it causes (Offer et al., 2000).

Claw lesions account for between $60 \%$ and $90 \%$ of all lameness incidences in cattle in various countries of the world (Bergsten et al., 1994; Manske et al., 2002; Weaver, 2000). More than $60 \%$ of lameness in cattle is caused by lesions and disorders affecting the horn of the claw such as sole ulcers, heel erosion, sole bruising, white line separation and underrun (double) soles. All these claw disorders and lesions have a direct or indirect effect on the dermis (corium) of the claw and are associated with laminitis ( Belge \& Bakir, 2005; Manske et al., 2002; Nocek, 1997). They are common in cattle raised under intense systems and feedlots (Smilie et al., 1991). Claw horn disorders in cattle are discernible at clinical level by lameness symptoms or at subclinical level by hoof trimming to reveal non-painful lesions within or under the horn (Clarkson et al., 1996; Nocek, 1997).

However, adoption of confined housing in dairy cattle husbandry as is the practice in smallholder dairy production systems particularly in developing countries has led to higher incidences of claw disorders. This is mainly due to cattle spending long hours standing on confined hard floors that exposes claws to higher pressures which predispose them to 
circumscribed excessive local loading, thus stimulating more horn production and enlarging of the claws. A positive correlation exists between the time cows spend on hard floors and development of claw horn lesions. This confinement further adversely affects behavior and welfare of cattle (Bergsten, 1994: Somers et al., 2003; van der Tol et al., 2003). These practices synergistically with high levels of concentrate diets exacerbate the occurrence of claw-horn disorders (Cook et al., 2004; Donovan et al., 2004; Nocek, 1997; Somers et al., 2005; Vermunt, 2004). Feeding cattle with diets that lead to low-grade prolonged lowering of rumen $\mathrm{pH}$ could result in an up-surge of lameness due to increased incidences of laminitis. Excessive feeding of rapidly fermented carbohydrates and finely chopped fodder silage enhance development of laminitis due to their tendency of initiating subacute ruminal acidosis (SARA), which is also aggravated by a fall in the ratio of concentrate to forage (C:F) (Vermunnt, 2004). However, supplementing cattle with minerals and vitamins tends to improve claw health and reduce likelihood of developing laminitis and sole lesions (Bergsten et al., 2003; Tomlinson et al., 2004). Previous publications based on retrospective data show that improvement of cattle housing in the zero-grazing units from earthen slurryladen floors to concrete floors, has led to a shifting from high prevalence of infective claw lesions and low prevalence of non-infectious laminitis related disorders to high prevalence of laminitis related disorders and low prevalence of infective claw lesions (Gitau, 1994; Mbithi et al., 1991; Nguhiu-Mwangi et al., 2009).

In developing Kenya where this research on association between non-infective claw disorders and risk factors was carried out, increased human population has led to inevitable reduction in per capita land-holdings. This has invariably led to diminished grazing land and subsequently triggering an increase in smallholder zero-grazing dairy production units particularly for the low income households (Mutugi, 2004). Rearing of dairy cows in smallholder zero-grazing units in developing countries is inevitable since they are part of the livelihood of the high population of low class smallholder farmers. For example in Kenya, smallholder units contribute $80 \%$ of the national commercial dairy herd (Wanyoike \& Wahome, 2004). These smallholder dairy production units in Kenya have varied designs and management practices. They are so varied unit to unit and sometimes within individual units that they can be further classified as subunits. They completely lack standardization of housing designs, nutritional regimen and management protocols (Nguhiu-Mwangi, et al., 2008). Prevalence of claw disorders in dairy cows raised under smallholder zero-grazing systems in Kenya and possible risk factors leading to development of these claw disorders has not been documented previously. Therefore, the study was carried out in Kenya to verify the types of claw disorders in dairy cows that are raised in the smallholder subunits under varied zero-grazing systems and to find out through statistical analysis whether there is any association between these subunit-level factors, animal-level factors and the claw disorders.

\section{Study procedures}

\subsection{Geographical study area}

This study was carried out in the peri-urban areas of Nairobi, Kenya in a period of six months (partly during the long rainfall season and partly during the short rainfall season). This is a fertile agricultural zone with an altitude of 1798 metres above sea level and has an annual rainfall estimated at a maximum of $765 \mathrm{~mm}$ and a minimum of $36 \mathrm{~mm}$ in two 
distinct seasons, March to June (long rainfall season) and October to December (short rainfall season) respectively.

\subsection{Zero-grazing unit and animal selection}

Evaluation of 32 smallholder zero-grazing dairy units purposively selected was done, in which cows were also examined for lameness and claw lesions. The zero-grazing units selected were those with 5-20 adult dairy cows. The farmers owning most of the zerograzing units were skeptical and hesitant to allow their dairy units evaluated or their cows examined. This was the reason for purposive selection of the zero-grazing units used in this study. The cows that were included in the study of claw lesions were those that had calved at least once with parities ranging between first and fourth. Those with $3^{\text {rd }}$ and $4^{\text {th }}$ parities were $60 \%$ and those with 1 st and $2^{\text {nd }}$ parities were $40 \%$ of the total population examined. All the selected cows whether lame or non-lame were examined. All the cows that had the study criteria were tagged with serial numbers $1,2,3$, to $n$, where $n$ was the serial number of the last cow being selected in the zero-grazing unit. To avoid biased numbering of the cows, assigning of serial numbers was randomly done by an independent worker employed in the zero-grazing unit. Then the author did the systematic selection of individual cows from the serialized groups by picking every second cow from the serial numbers. For example in the serial $n_{1}$ to $n_{10}$, if the first cow selected was $n_{1}$, the next serially selected would be those with odd serial numbers $\left(n_{1}, n_{3}, n_{5}, n_{7}\right.$, and $\left.n_{9}\right)$. But if the first cow selected was $n_{2}$, the next serially selected would be those with even serial numbers $\left(n_{4}, n_{6}, n_{8}\right.$ and $\left.n_{10}\right)$. The serial numbers of the first cow selected was alternated between $n_{1}$ and $n_{2}$ from one zero-grazing unit to the next. Therefore, the cows selected in any zero-grazing unit were all those with either odd or even serial numbers.

\subsection{Study design and data collection}

The data were collected in a cross-sectional study in which each smallholder zero-grazing dairy unit was visited only once. During the single visit, the zero-grazing unit was evaluated and data recorded on possible risk factors of claw conditions. The selected cows were also evaluated for claw lesions as well as animal-level risk factors of claw lameness conditions. Data on animal-level risk factors were collected by the author administering questionnaires to the farmers or to the persons employed to manage the zero-grazing units as respondents before examination of each cow. These data included breed of the cow, parity, milk yield per day and lactation stage. The questionnaires were structured with simple "Yes" or "No" and "I do not know" responses to minimize variations and information bias from the respondents. From the 32 smallholder zero-grazing units, 300 dairy cows were examined for claw lesions and animal-level risk factors. Out the 300 cows, Friesians were $76 \%$ (228), Ayrshires 20\% (60) and the remaining 4\% (12) were a mixture of Guernsey and Jersey. Data from unit-level risk factors were collected during visitation to each of the 32 smallholder zero-grazing units. Some of the data (housing and stall design, number of cubicles, type of cubicle bedding, type of floor, presence or absence of a curb (kerb) at the rear end of the cubicles, lunging space, bob zone, presence or absence of neckbar over the feeding bunk/trough and adequacy of feeding space) were collected through observational (qualitative) method. Other data such as curb height and height of neck-bar from the top surface of feeding trough were collected through actual measurements, while 
the rest (frequency and amount of concentrate feeding, mineral supplementation, type of fodder, and frequency of manure removal from the walk-alleys were collected by the author interviewing the farmers or the persons managing the zero-grazing units. All the data both for animal-and unit-level risk factors were entered into the questionnaires using codes adopted at the pre-coding stage during an initial pilot study in 5 sample smallholder zerograzing dairy units.

\subsection{Examination of the cows for claw lesions}

Each cow was examined for general lameness using universally described locomotion scoring system (Sprecher et al., 1997). Data on claw disorders were collected by examining each claw on each cow. Each cow was restrained in a standing posture in a restraining area (crush). The limbs were lifted one at a time by tying with a rope and fastening the rope to an overhead pole or cross-bar. In that raised position, each claw was thoroughly washed with soap and water and examined for any lesions particularly on the weight-bearing surface. About 1-2 mm thickness of the horn of the sole was trimmed-off using a sharp quitter knife to expose any underlying lesions particularly sole haemorrhages. Trimming did not reach the level of corium and therefore no pain was caused on the cows. In cases with painful claw conditions, foot anaesthesia using $2 \%$ lignocaine hydrochloride was applied to allow painless manipulation. The lesions found on each cow were recorded.

\subsection{Data management and analysis}

The data were entered and stored in Microsoft Office Excel 2003. After verification and validation of data, they were imported into SAS ${ }^{\odot}$ 2002-2003 (SAS Institute Inc., Cary, NC, USA). Descriptive statistics were computed for cow-level and unit-level risk factors. The prevalence rate of each claw disorder was calculated independent of other claw disorders. The prevalence of each claw disorder was calculated as the number of cows affected by the specific claw disorder or lesion (nCL) divided by the total number of cows (300) examined, and then multiplied by 100.

$$
\text { Prevalence }(\%)=\frac{n C L}{100} x 100
$$

Chi-square $\left(\chi^{2}\right)$ statistics were used to determine unconditional associations between all risk factors and the claw lesions. An association was considered significant at the level of $p<0.05$. Chi square values were determined using $2 \times 2$ contingency tables constituting 2 rows and 2 columns. In these associations the Chi square calculations were determined by evaluating each risk factor (variable) against each claw disorder (outcome) on the cow. The degrees of freedom (df) in each case was standard, being calculated by:

$$
\text { [(row-1) } \times \text { (columns-1)], hence [(2-1) x (2-1)] }
$$

Therefore, $\mathrm{df}$ was 1 for each association test. Multiple logistic regressions were done through a step-down regression in which the risk factors that made the least variation to the occurrence of the claw lesions were eliminated one at a time through consideration of their odds ratios. Only the factors that were found to influence the occurrence of claw lesions significantly were retained in the model. The effects of confounding risk factors were dealt 
with in the analysis but they were minimal because of some similarities in the management between the smallholder zero-grazing units.

\section{The study findings}

\subsection{Prevalence of claw disorders found in the study}

The results of this study revealed that cows from the varied smallholder zero-grazing dairy units had a high (88\%) prevalence of claw lesions, $69 \%$ of which did not manifest lameness but had subclinical disorders and only $31 \%$ were lame. Some of the cows had more than one claw disorders concurrently. Laminitis had the highest prevalence (70.3\%), with subclinical laminitis at $49.3 \%$ and chronic laminitis at $21 \%$. Other non-infectious claw disorders with high prevalence were sole bruising (erosion) at $45 \%$, claw overgrowth at $30 \%$, heel erosion at $27.3 \%$, white line separation at $18 \%$ and underrun (double) soles at $17 \%$. Infective lesions had very low prevalence of $4.7 \%$ (Table 1 ).

\begin{tabular}{|l|c|c|}
\hline Claw lesions & Number of cows $(\mathrm{n}=300)$ & Prevalence (\%) \\
\hline Subclinical laminitis & 148 & 49.3 \\
\hline Chronic laminitis & 63 & 21.0 \\
\hline Laminitis-related disorders & \multicolumn{2}{|c|}{} \\
\hline Sole bruising & 135 & 45.0 \\
\hline Heel erosion & 82 & 27.3 \\
\hline White line separation & 54 & 18.0 \\
\hline Underrun (double) soles & 51 & 17.0 \\
\hline Sole ulcer & 8 & 2.7 \\
\hline sole foreign bodies & 1 & 0.3 \\
\hline Laminitis-related claw deformities & \multicolumn{2}{|l|}{} \\
\hline Claw overgrowth & 91 & 30.3 \\
\hline Claw horn deep horizontal grooves & 53 & 17.8 \\
\hline Flattened claws (reduced toe angle) & 36 & 12.0 \\
\hline Splayed toes & 26 & 8.7 \\
\hline Concaved dorsal claw wall & 15 & 5.0 \\
\hline Corkscrewed claws & 14 & 4.7 \\
\hline Non-laminitis lesions & \multicolumn{2}{|l|}{} \\
\hline Claw infective lesions & 14 & 4.7 \\
\hline Claw traumatic lesions & 2 & 0.7 \\
\hline Growths in the foot soft tissues & 2 & 0.7 \\
\hline
\end{tabular}

(NB: Some of the cows had more than one claw disorders concurrently, hence percentage totals of more than 100).

Table 1. Prevalence of claw disorders and lesions and their prospective risk factors as found during a cross-sectional study in dairy cows in varied smallholder zero-grazing dairy units in Kenya.

Among the cows that had chronic laminitis, $85 \%$ had more than two other concurrent claw disorders such as underrun (double) soles, sole bruising, heel erosion and white line separation. In addition, all the cases of chronic laminitis invariably had one or more ways in 
which the claw was misshaped such as excessive elongation, abnormal widening, excessive flattening, concavity of the dorsal wall and deep horizontal grooves (ridges) on the dorsal and the lateral walls. When chronic laminitis was found in any cow, it was always bilateral affecting all the claws but more often the hind limbs. Such cows were invariably lame.

\subsection{Description of the non-infectious claw disorders found in this study}

Lesions on the weight-bearing surface of the claw were described mainly according to the zones they affected. The six zones on the weight-bearing surface of the claw were universally described previously denoted as zone 1 (white line at the toe), zone 2 (abaxial white line), zone 3 (abaxial wall-bulb junction), zone 4 (sole-bulb junction), zone 5 (apex of the sole) and zone 6 (the bulb) (Greenough \& Vermunt, 1991).

\subsubsection{Subclinical laminitis}

Cows with subclinical laminitis had normal gait. The only way of confirming subclinical laminitis was by trimming-off a thin layer of the horn of the sole. The main sign of subclinical laminitis was sole haemorrhages seen as reddish or yellow-waxy discolourations after trimming of the superficial layers of the horn of the sole. The haemorrhages in subclinical laminitis appeared in one or at most two zones of the weight-bearing surface of the claw (Fig. 1). In a few instances, the haemorrhages were visible on the surface of the horn of the sole even before trimming. Sole haemorrhages were scored according a universally suggested scale denoted as score 0 (no haemorrhages), score 1 (slight haemorrhages), score 2 (moderate haemorrhages), score 3 (severe haemorrhages), and score 4 (exposed corium) (Greenough \& Vermunt, 1991). The haemorrhages were highly prevalent in zone $4(34.7 \%)$, moderately prevalent in zones 3(14.3\%), $6(14.1 \%)$ and $2(13.6 \%)$, and least prevalent in zones 5 and 1 at $8.7 \%$ and $0.7 \%$ respectively (Nguhiu-Mwangi et al., 2007). Haemorrhage score and the number of haemorrhagic zones had a strong positive correlation $(\mathrm{r}=0.546, \mathrm{O} . \mathrm{R} .=21.24)$ with subclinical laminitis and this correlation was highly significant $\left(\chi^{2}=89.45, p<0.05\right)$. Subclinical laminitis was mainly associated with haemorrhages in zone 4 and the abaxial whilte line (Fig. 1) and these associations were significant $\left(\chi^{2}=22.83, p<\right.$ $0.05)$. Occurrence of sole haemorrhages was significantly $\left(\chi^{2}=86.5, p<=0.001\right)$ higher in the hind lateral claws than the medial claws. Among the cows with subclinical laminitis, $32.4 \%$ manifested with only sole haemorrhages but $67.6 \%$ concurrently manifested sole haemorrhages as well as one or two of the other claw lesions such as sole bruising, heel erosion and white line separation.

\subsubsection{Chronic laminitis}

Claws with chronic laminitis had severe and widespread haemorrhages affecting several zones of the weight-bearing surfaces of the claws (Fig. 2). Haemorrhages in chronic laminitis could be visible on the surface of the sole before trimming. Haemorrhage score and the number of haemorrhagic zones had a positive correlation $(\mathrm{r}=0.41)$ and the correlation was highly significant $\left(\chi^{2}=50.16, p<0.05\right)$. Haemorrhages in chronic laminitis significantly affected mainly zones $3\left(x^{2}=23.45, p<0.05\right)$, and $2\left(\chi^{2}=18.23, p<0.05\right)$ and occasionally but weakly zone $6\left(\chi^{2}=4.48, p<0.05\right)$. In addition to haemorrhages, $84.8 \%$ of the cows with chronic laminitis also had more than two other claw lesions such as double soles, sole bruising, heel erosion and white line separation. All cases of chronic laminitis, almost 

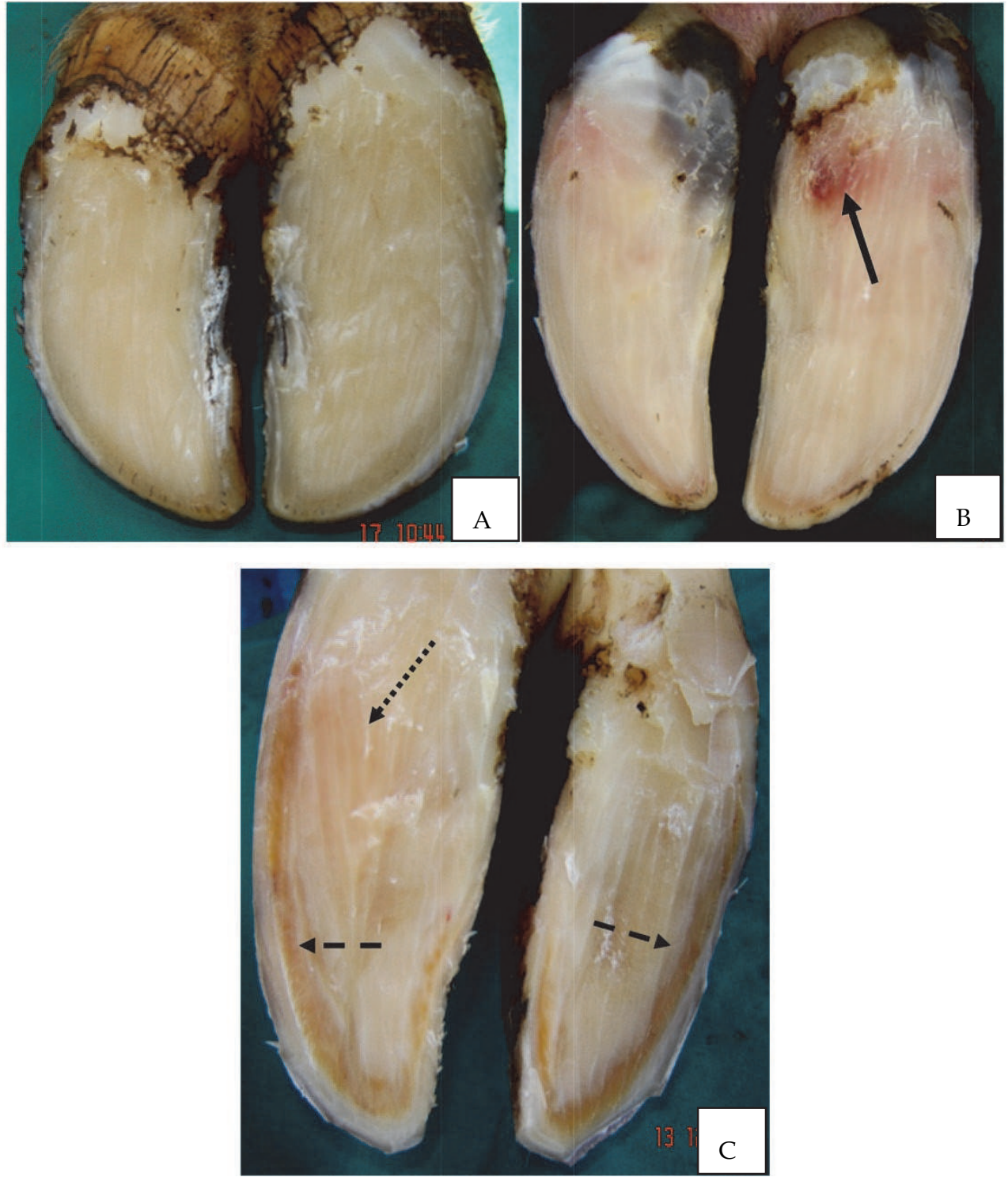

Fig. 1. Sole haemorrhages exposed after trimming of the horn of the sole signifying presence of subclinical laminitis in the claws of dairy cows examined in smallholder zero-grazing dairy units in the peri-urban areas of Nairobi, Kenya. A: normal claw with no haemorrhages; B: slight haemorrhages in zone 4 (bold arrow); C: moderate haemorrhages in the abaxial and a bit of axial white line (dashed arrows), as well as on zones 4 and 5 (dotted arrow). 

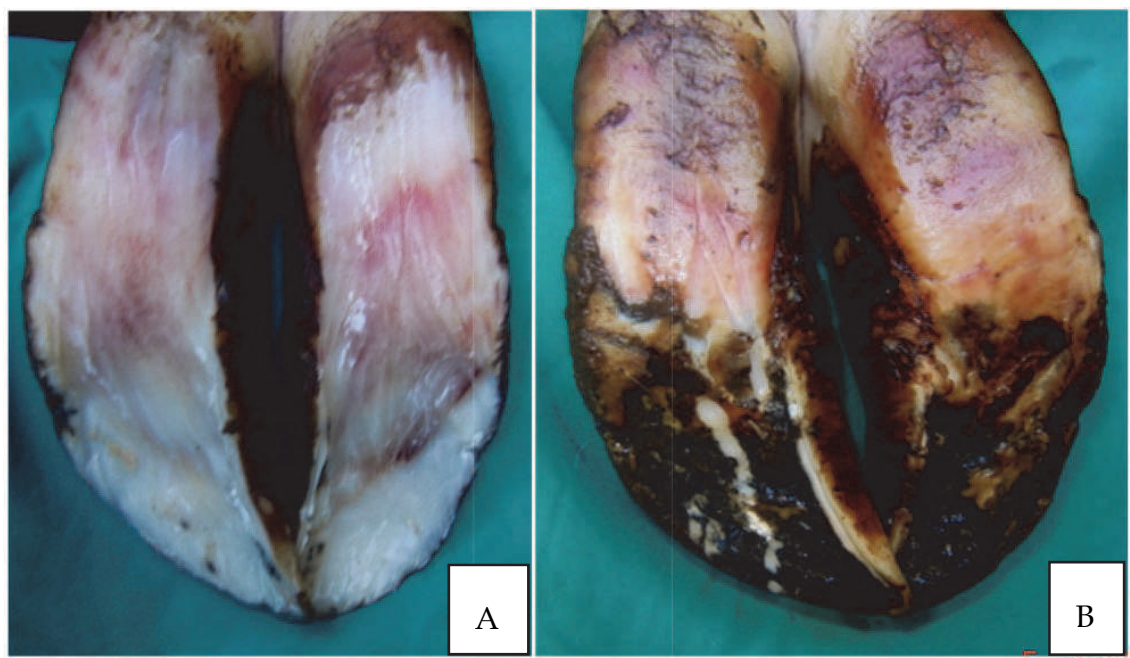

Fig. 2. Severe widespread haemorrhages affecting most zones of the weight-bearing surfaces of the claws in one of the cows examined during the study of claw disorders and their prospective risk factors in the smallholder zero-grazing dairy units in the peri-urban areas of Nairobi, Kenya. The haemorrhages are seen as reddening of the horn of the sole. A: haemorrhages seen after trimming of the horn of the sole; B: haemorrhages seen superficially on the weight-bearing surface before trimming.

invariably had misshapen claws resulting from either overgrown, elongated, widened, flattened or concaved claws and all of them with deep prominent horizontal ridges of the dorsal and lateral walls (Fig. 3). Chronic laminitis in each cow was invariably bilateral, which together with misshaped claws exacerbated poor locomotion and hence the animals were found to always have moderate degree of lameness. Some of the claws were extremely misshapen to the extent that re-shaping them back to normal would be impossible. On trimming some of the claws with chronic laminitis, they were found to have weak whitish crumbling horn (Fig. 4).
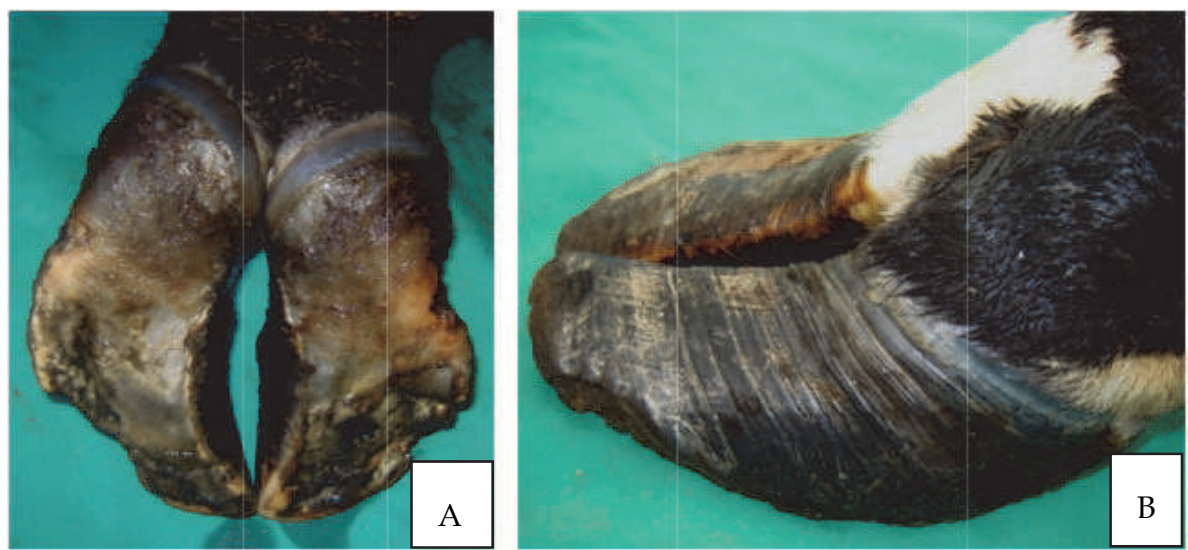

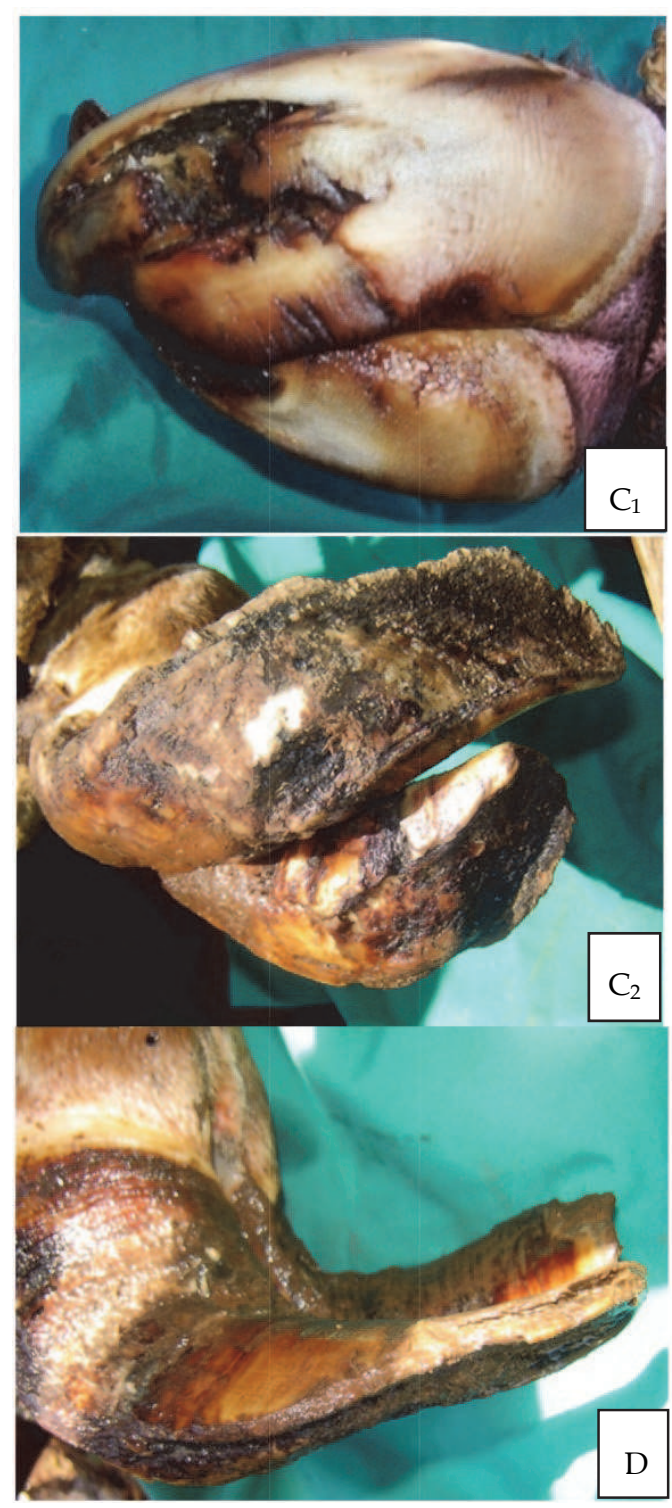

Fig. 3. The different forms of misshaping of the claws with chronic laminitis observed in dairy cows during a study on prevalence of claw disorders and the possible risk factors in smallholder zero-grazing dairy units in the peri-urban areas of Nairobi, Kenya.

A: irregularly widened claws; B: elongated flattened claws, reduced toe angle and heel height and presence of deep prominent horizontal ridges on the dorsal and lateral walls; $\mathrm{C}_{1}$ and $\mathrm{C}_{2}$ : elongated overlapping claws with extreme concavity of dorsal wall and convex weight-bearing surface; D: elongated flattened claw, toe angle greatly reduced and concavity of dorsal walls of the claw. 


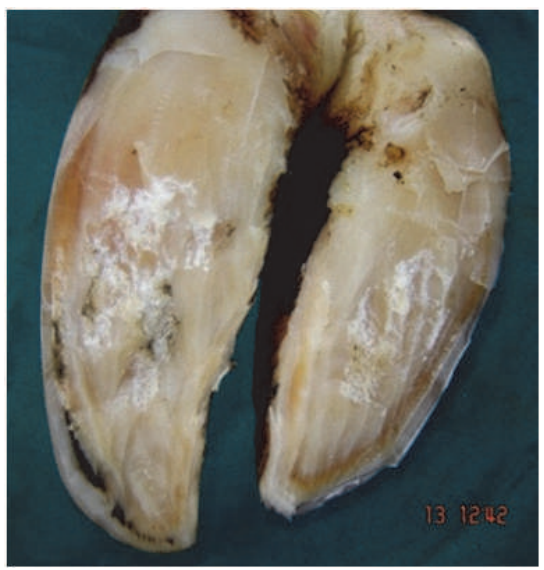

Fig. 4. Softened whitish crumbling horn of the sole in a claw with chronic laminitis found in one of the cows during the study of prevalence and risk factors of claw lesions in smallholder zero-grazing dairy units in the peri-urban areas of Nairobi, Kenya.

\subsubsection{Sole bruising}

Sole bruising was seen as erosive areas of black necrotic-like horn. In the cows with less erosive sole bruising, it involved zone 5 only. The more invasive erosions of the sole involved zones 1, 4 and 5 simultaneously. In the less severe sole bruising, there was erosion of only the superficial parts of the horn of the sole, but in the severe sole bruising, there was invasive erosion deeper into the horn of the sole, which when trimmed revealed that only a very thin layer of the horn was left intact (Fig. 5). Sole bruising was always found to be bilateral affecting either only the lateral claws, or only the medial claws. It very occasionally involved lateral and medial claws simultaneously. It was observed to affect the claws of all the feet, but particularly common on the hind feet claws.
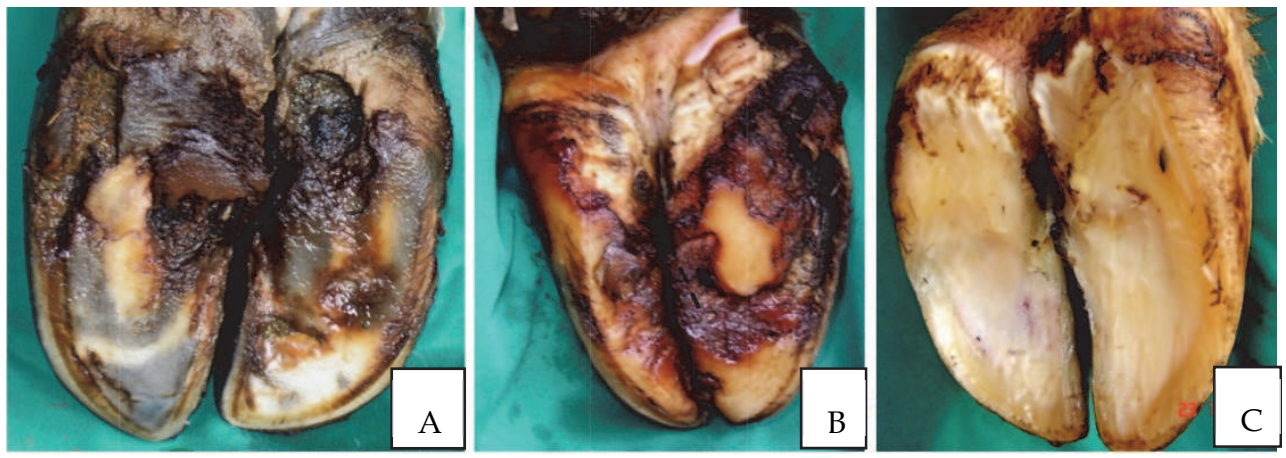

Fig. 5. Sole bruising in claws of cows observed during a study of prevalence and risk factors of claw disorders in smallholder zero-grazing dairy units in Kenya. A: superficial noninvasive sole bruising mainly in zone 5; B: deeper erosive and invasive sole bruising involving zones 1, 4 and 5, with only a small part at the centre remaining not eroded; C: thin layer of the horn left in a section of the sole after trimming areas that had sole bruising 


\subsubsection{Heel erosion}

Heel erosion like sole bruising appeared as dark necrotic areas of the horn predominantly in zone 6. However, when deeply invasive, it occasionally extended to zones 3 and 4 (Fig. 6). Heel erosion was invariably bilateral and in the hind limbs it affected either lateral claws only, or medial claws only, but occasionally it affected both lateral and medial claws concurrently. When present in any herd, it was observed to affect all the cows in the zerograzing unit without any exception. Some of the claws with heel erosion had some degrees of sole bruising at the same time.

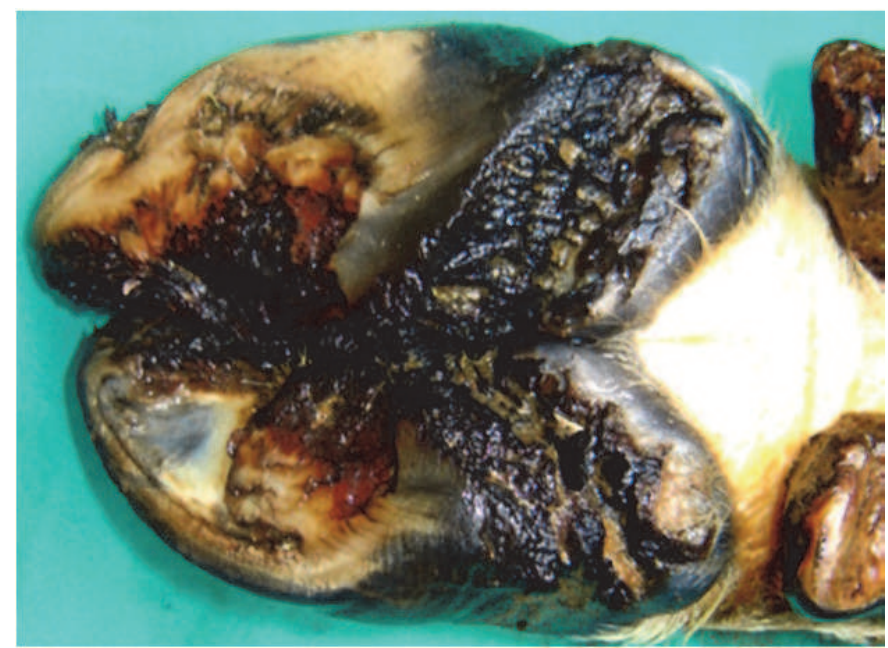

Fig. 6. Severely erosive and invasive heel erosion involving zones 6, 4 and 3 in both claws of a cow seen during the study of prevalence and risk factors of claw disorders in smallholder zero-grazing dairy units in Kenya. There is also sole bruising affecting the axial part of zone 5 .

\subsubsection{Underrun (double) soles}

Underrun sole involved separation of the horn of the sole into two distinct layers constituting a superficial thicker harder sole and a thinner softer underlying sole. It was diagnosed by thoroughly washing the claws, which made it possible to see dung and debris stuck underneath the superficial sole. In some of the cases, it was only diagnosed during trimming by incidental finding of a superficial horn layer completely detached from a thinly forming underlying horn layer (Fig. 7). A claw that had double soles appeared grossly wider than both the normal ipsilateral and contralateral claws. Double sole phenomenon was common in zones 4 and 5 . In some of the cows it was unilateral while in others it was bilateral affecting the contralateral claw on the opposite limb. Superficially traumatized horn of the sole was encountered in two cows in which the top sliced horn still attached to the underlying remaining horn at some point (Fig. 8), which erroneously can be diagnosed as underrun sole. The margins of the traumatized horn of the sole cleared appeared as distinct cut edges compared to those of underrun sole, and the underlying horn in the case of trauma was hard compared to the thin horn of the underrun sole. 

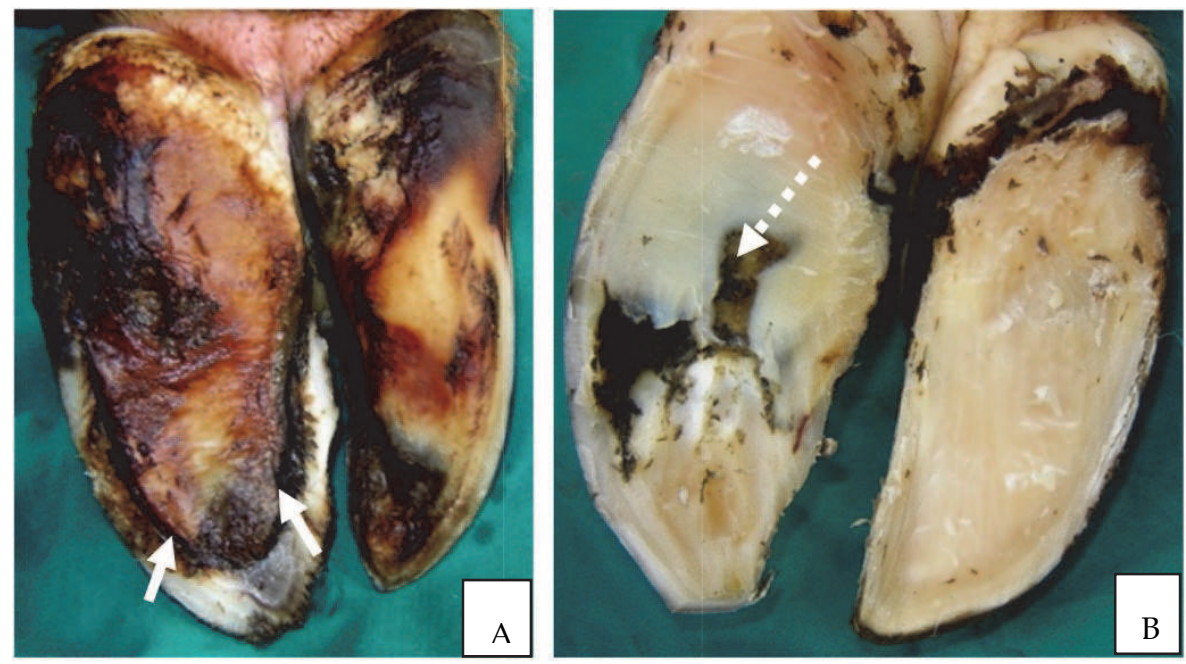

Fig. 7. The left claw in A and B has underrun (double) soles and is wider than the normal ipsilateral claw. This was seen in a cow examined during a study on prevalence and risk factors of claw disorders in smallholder zero-grazing dairy units in the peri-urban areas of Nairobi, Kenya. A:underrun sole before trimming with the margins of the superficial sole clearly demarcated (arrows); B: underrun sole after trimming, the dung matting underlying thin sole can be seen (dashed arrow).
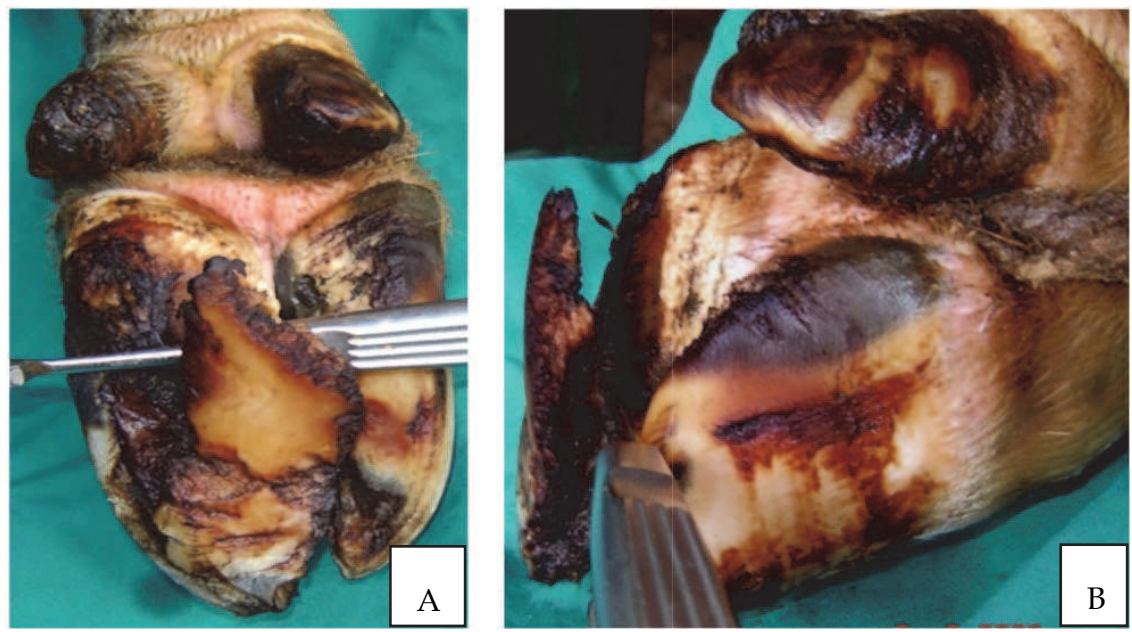

Fig. 8. Traumatized horn of the claw observed in 2 cows during the study of prevalence and risk factors of claw lesions in smallholder zero-grazing dairy units in the peri-urban areas of Nairobi, Kenya. A: plantero-dorsal view with the metallic quitter knife pointer between the detached horn and underlying horn; B: lateral view with the metallic quitter knife pointer between the detached horn and underlying horn. 


\subsubsection{White line separation}

White line separation was seen as clear separation of the horn of the sole and the wall. It was more discernible after thorough washing of the claws and trimming the horn of the sole (Fig. 9). The gap between the avulsed horn of the sole and the wall was usually filled with dung and debris, and in addition it could also oozed infective exudates if sepsis had set into the separated white line. White line separation involved mainly zone 2, but also very occasionally the axial part of zone 4 and 5, and sometimes zone 3 . It was invariably unilateral involving only one claw.
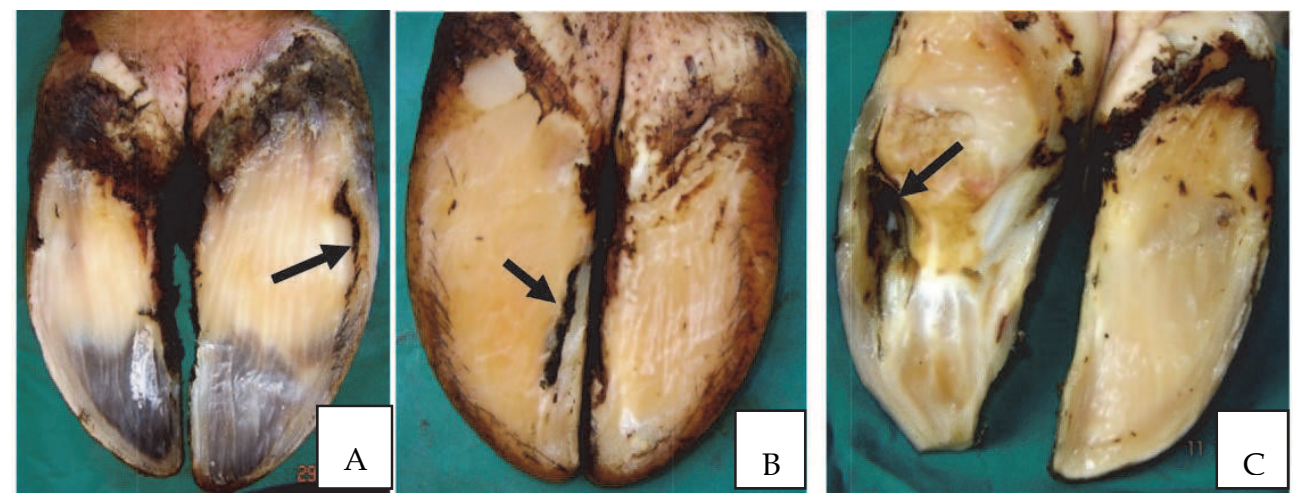

Fig. 9. Various degrees of white line separation seen after trimming of the horn of the sole in some of the cows examined during the study of prevalence and risk factors of claw lesions in smallholder zero-grazing dairy units of the peri-urban areas of Nairobi, Kenya. A: moderate separation on the abaxial white line (arrow); B: moderate separation on the axial white line (arrow); C: extensive avulsion of the white line with invasive infection (arrow).

\subsubsection{Sole ulcer}

Occurrence of sole ulcers exposes the corium. In this study, it occurred in $3 \%$ of the cows and invariably resulted in severe lameness. All the sole ulcers occurred at the inner part of zone 4 and were unilateral affecting only one claw in each case. Each sole ulcer had a mass of protruding granulation tissue growing out of the site of the exposed corium (Fig. 10).

\subsubsection{Claw deformity disorders}

In this study, $43.7 \%$ of the cows examined had one or more types of claw deformities. There were several types of claw deformities and a number of them occurred concurrently in the same cow. Cows with claw overgrowth had entire toe, sole and walls overgrown ranging from slight to extreme overgrowth and with subsequent misshaping or deformity of the claw (Fig. 11) and consequently abnormal gait. The deformities observed were upward (dorsal) turning or crookedly shaped toe (Fig. 12), irregularly widened claw (Fig. 3 and 11), concaved claw (Fig. 3), elongated flattened claw (Fig. 3 and 11), lateral claw wall turned sole-ward (ventral) to the treading surface (Fig. 13), which was observed in 3 cows, crossed toes or scissor feet (Fig. 14) and prominent deep horizontal ridges on the dorsal wall of the claw (Fig. 3). Claws that had these characteristics in most cases also had chronic laminitis as 
evidenced by underlying sole haemorrhages on trimming of the horn of the sole and some even before trimming (Fig. 2). Splaying of the claws was found independent of other deformities but occasionally concurrent with claw overgrowth (Fig. 15). Corkscrew claw was not common but when encountered, it was bilateral involving only medial claws or only lateral claws of fore or hind limbs (Fig. 16).

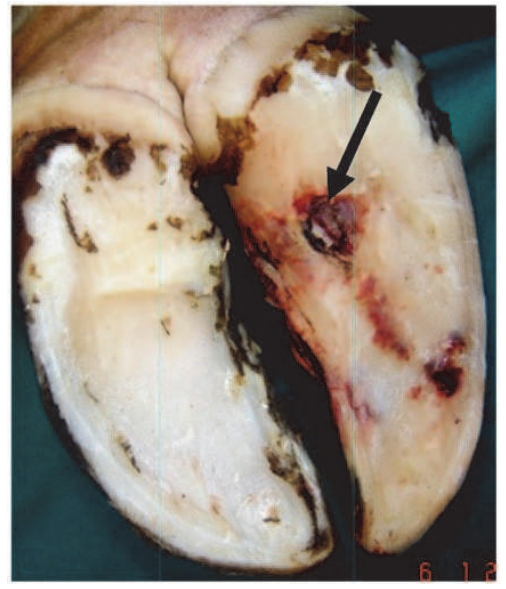

Fig. 10. Sole ulcer with protruding mass of granulation tissue (arrow) seen clearly after trimming of the horn of the sole in some cows during the study of prevalence and risk factors of claw lesions in smallholder zero-grazing dairy units in the peri-urban areas of Nairobi, Kenya. The affected claw also has sole haemorrhages, thus indicating presence of laminitis.
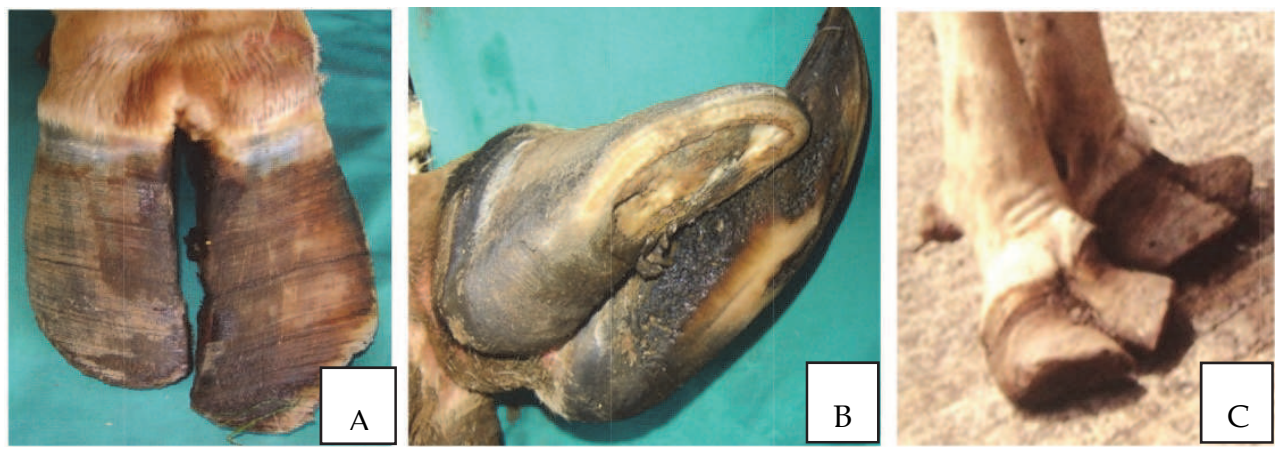

Fig. 11. Regular overgrowth showing claw widening (A), toe elongation (B), as well as widening, flattening and change of treading angle of the claw to more proximal parts toward the heel $(\mathrm{C})$. These were observed in some of the cows examined during the study of prevalence and risk factors of claw lesions in smallholder zero-grazing dairy units in the peri-urban areas of Nairobi, Kenya. 


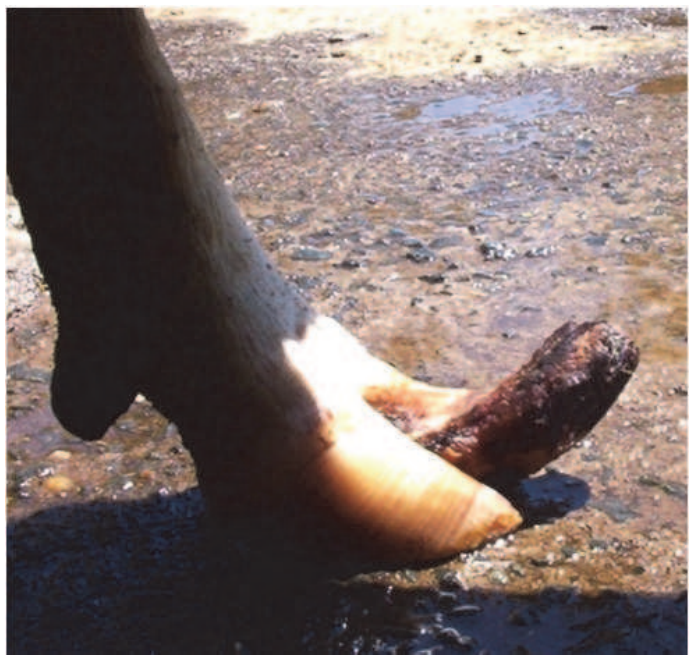

Fig. 12. Crookedly twisted and upward (dorsal) turning of the claw of a cow observed during the study of prevalence and risk factors of claw lesions in smallholder zero-grazing dairy units in the peri-urban areas of Nairobi, Kenya.

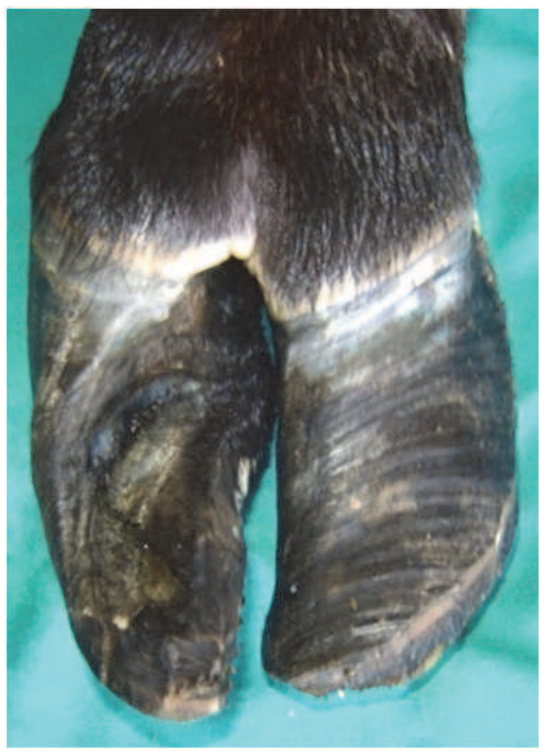

Fig. 13. Spiraling of the lateral wall of the claw of a cow with abaxial aspect turning to face ventral toward the treading surface and the axial aspect turning to face dorsally. This was observed during the study of prevalence and risk factors of claw lesions in smallholder zerograzing dairy units in the peri-urban areas of Nairobi, Kenya. 

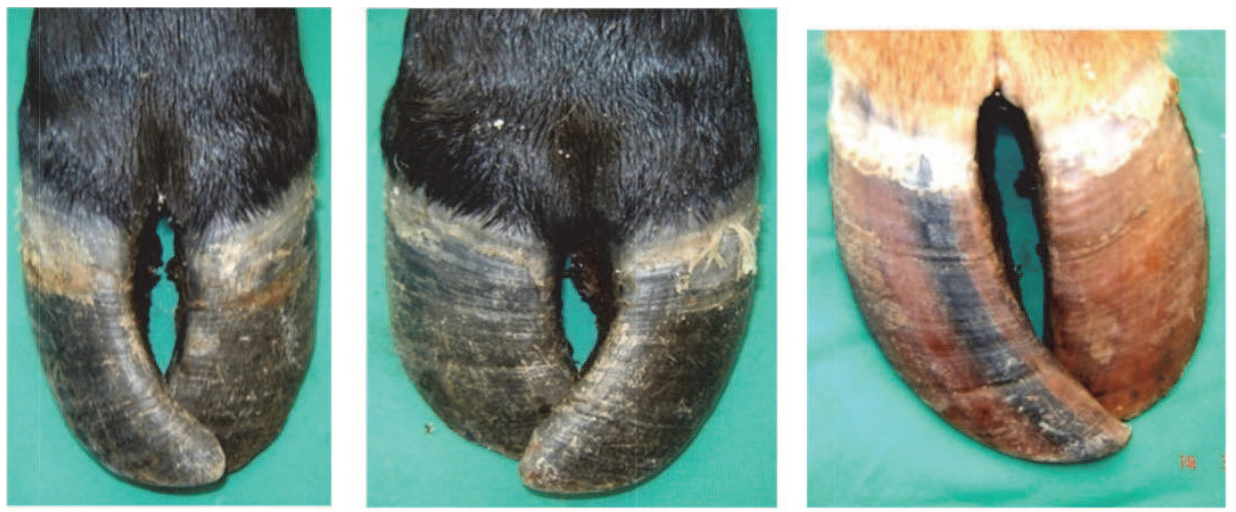

Fig. 14. Bilateral crossed toes or scissor feet in cows due to overgrown claws overlapping over each other. These were observed during the study of prevalence and risk factors of claw lesions in smallholder zero-grazing dairy units in the peri-urban areas of Nairobi, Kenya.
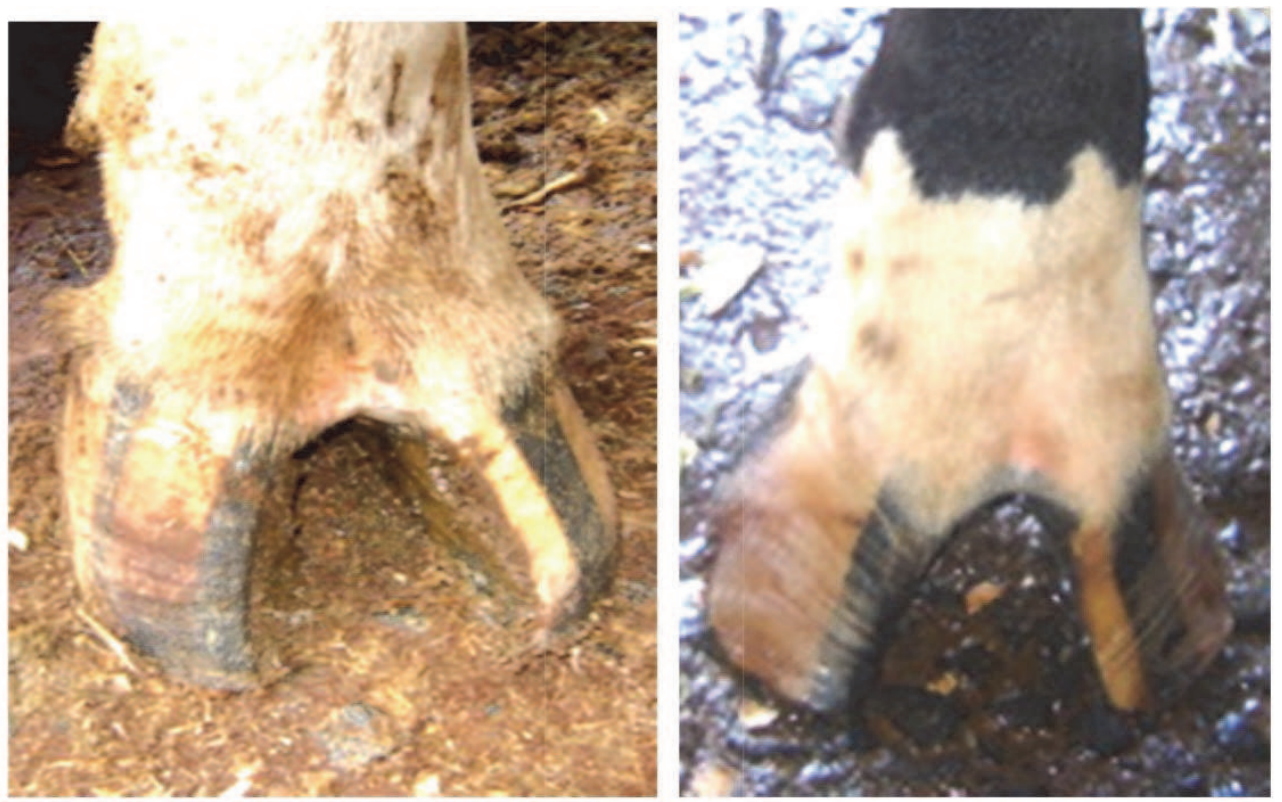

Fig. 15. Splayed toes observed in cows examined during a study of prevalence and risk factors of claw lesions in smallholder zero-grazing dairy units in the peri-urban areas of Nairobi, Kenya. 

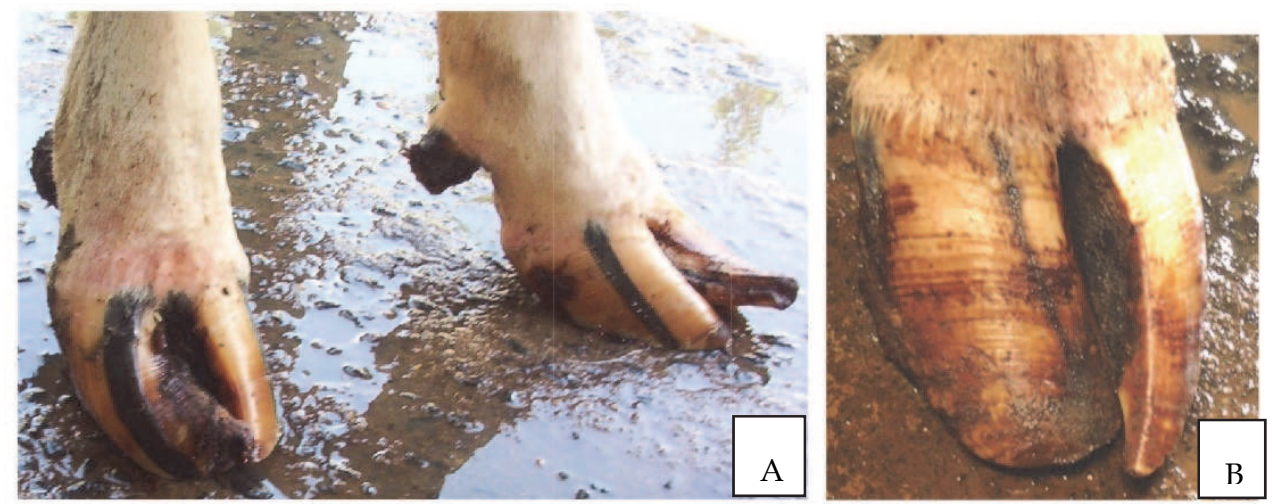

Fig. 16. Two stages of corkscrew claw seen in the cows examined during a study of prevalence and risk factors of claw lesions in smallholder zero-grazing dairy units in the peri-urban areas of Nairobi, Kenya. A: shows severe bilateral corkscrew on both lateral claws, while both medial claws are normal and, B: mild corkscrew on one of the claws spiraling toward the normal claw.

\subsection{Description of risk factors}

\subsubsection{Cow housing factors}

Good concrete floors (with firm ground-grip, non-slip and without pot-holes) were present in $68.8 \%$ of the zero-grazing units. The rest $(31.2 \%)$ of the units had floors that were concreted but with loose stones, over-smoothened and slippery, grossly worn out with small to large pit-like patches, or earthen (bare soil). Among these floors, $62 \%$ had slight to moderate floor slope (<3\% gradient), while 9\% had steep slope ( $>3 \%$ gradient) and $29 \%$ had no slope at all but were flat. A total of $59 \%$ of the zero-grazing units were stocked to capacity (cubicle to cow ratio 1:1). The other $41 \%$ were over-stocked (more cows than cubicles). The proportion of the zero-grazing units without cubicle bedding was $38 \%$, in which the animals lay directly on bare concrete and in some of them there were loose stones present on the cubicle floor (Fig. 17a). In those with cubicle bedding, the bedding was wood shavings, sawdust, soil, sand, rice husks, or rubber mats (Fig. 17b).

The neck-bar height of $0.6 \mathrm{~m}$ from the upper-level of the feeding bunk was considered to be optimal. Only in $57 \%$ of the zero-grazing units were the neck-bars $\geq 0.6 \mathrm{~m}$ high, but in the other $43 \%$ of the units the neck-bars were $<0.6 \mathrm{~m}$ high. In $63 \%$ of the zero-grazing units, the lunging space (for the forward head movement during the act of standing) was $\geq 0.4 \mathrm{~m}$, but in $37 \%$ of the units, it was $<0.4 \mathrm{~m}$ and the cow's head was in contact with the wall of the cubicle. In $72 \%$ of the units, the bob zone (for up-down movement of the head during the act of standing) was adequate between $0.4 \mathrm{~m}$ and $0.6 \mathrm{~m}$ from the ground to the cubicle crossbar, while in $28 \%$ of the zero-grazing units, the bob zone was inadequate at $<0.4 \mathrm{~m}$ in which the cows struggled during the act of standing with the dorsal part of the neck coming into contact with the cross bar before fully standing (Fig. 18).

Presence of a curb (kerb) on the rear end of a cubicle was considered as a possible risk factor for development of non-infective claw disorders. Cubicle curb-height of 10-15 cm was 
considered as normal. Only $50 \%$ of the zero-grazing units had cubicle curbs among which $19 \%$ had cubicle curbs that were between $10 \mathrm{~cm}$ and $15 \mathrm{~cm}$ tall, while $31 \%$ had cubicle curbs that were more than $15 \mathrm{~cm}$ tall that presented difficulties for the cows to walk backwards off the cubicles. The other $50 \%$ of the zero-grazing units had cubicles that did not have any curbs. In $88 \%$ of the zero-grazing units, the feeding area was adequate space $(\geq 0.8 \mathrm{~m}$ per cow) for all the cows to feed simultaneously. In most of them the older and the younger stock fed separately. In $12 \%$ of the units, the feeding area was inadequate space $(<0.8 \mathrm{~m}$ per cow) due to overstocking.
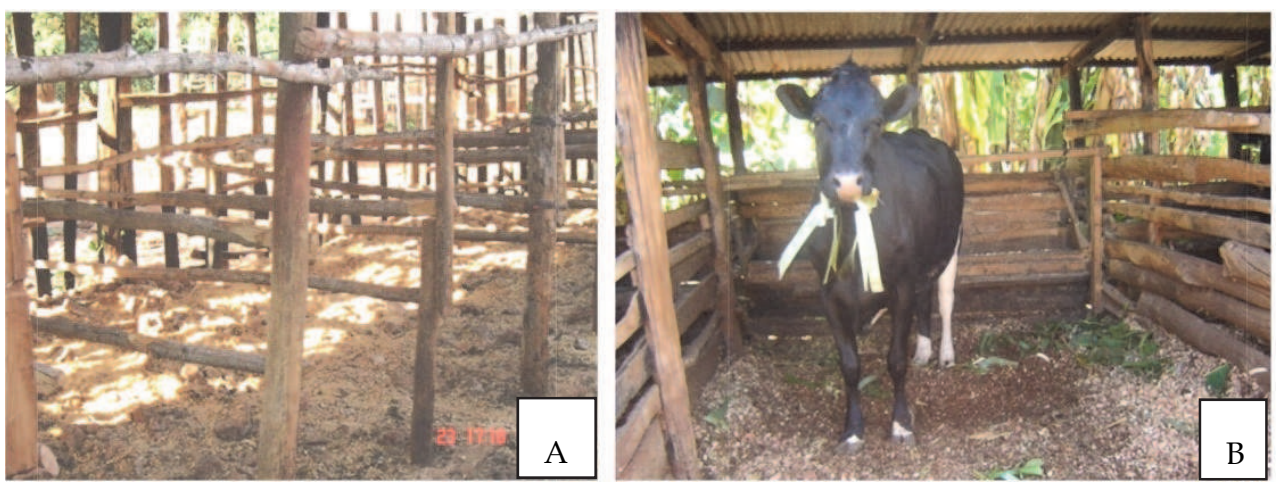

Fig. 17a. A: bare cubicle without bedding but with loose stones, B: cubicle with wood shaving bedding. These were seen during the study of prevalence and risk factors of claw lesions in cows in smallholder zero-grazing dairy units in the peri-urban areas of Nairobi, Kenya.
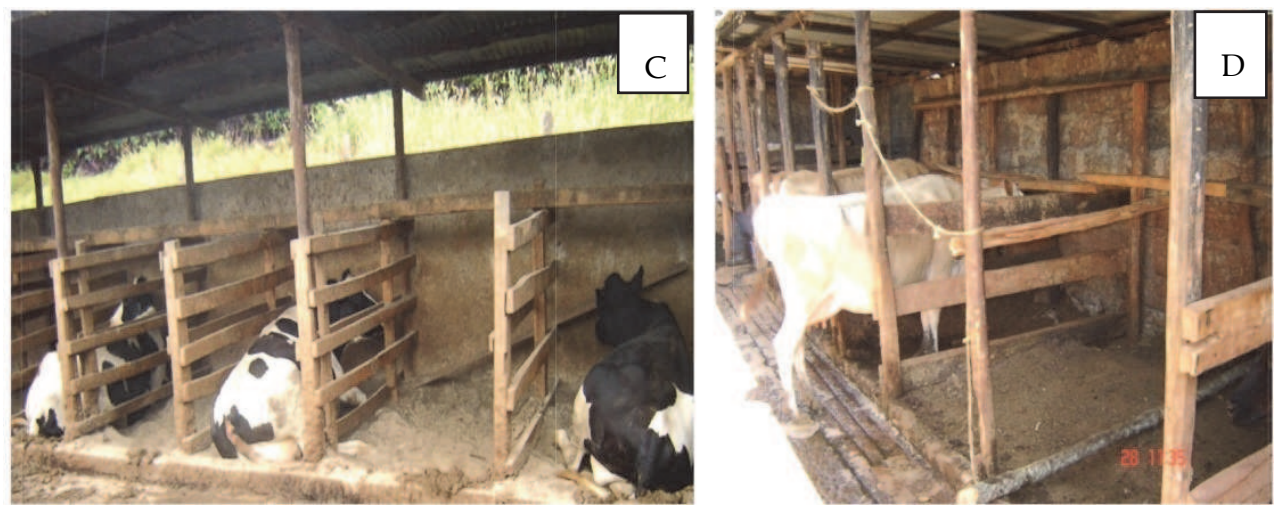

Fig. 17b. C: cubicles with sand bedding, D: cubicles with soil bedding and 


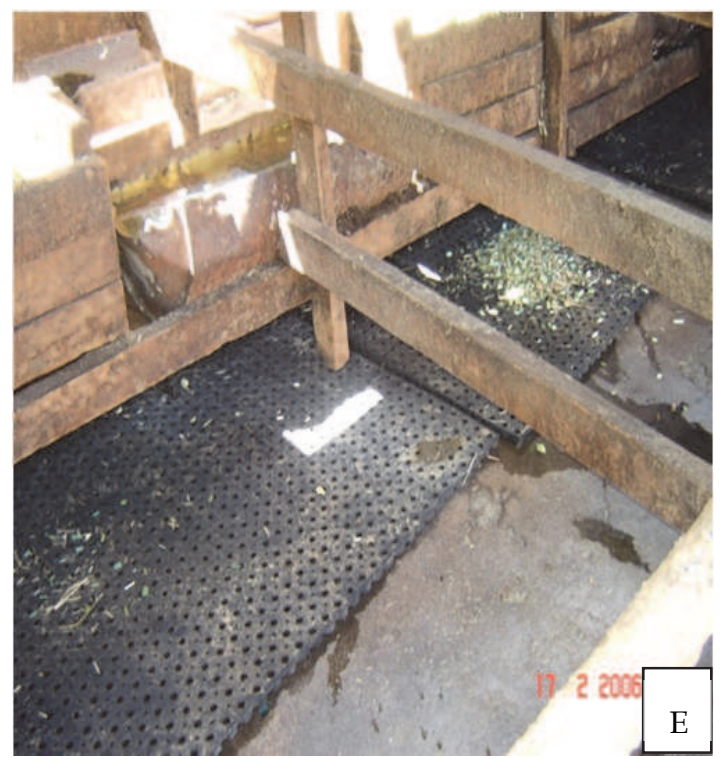

Fig. 17b. E: cubicles with partial rubber mat covering. These were seen during the study of prevalence and risk factors of claw lesions in cows in smallholder zero-grazing dairy units in the peri-urban areas of Nairobi, Kenya

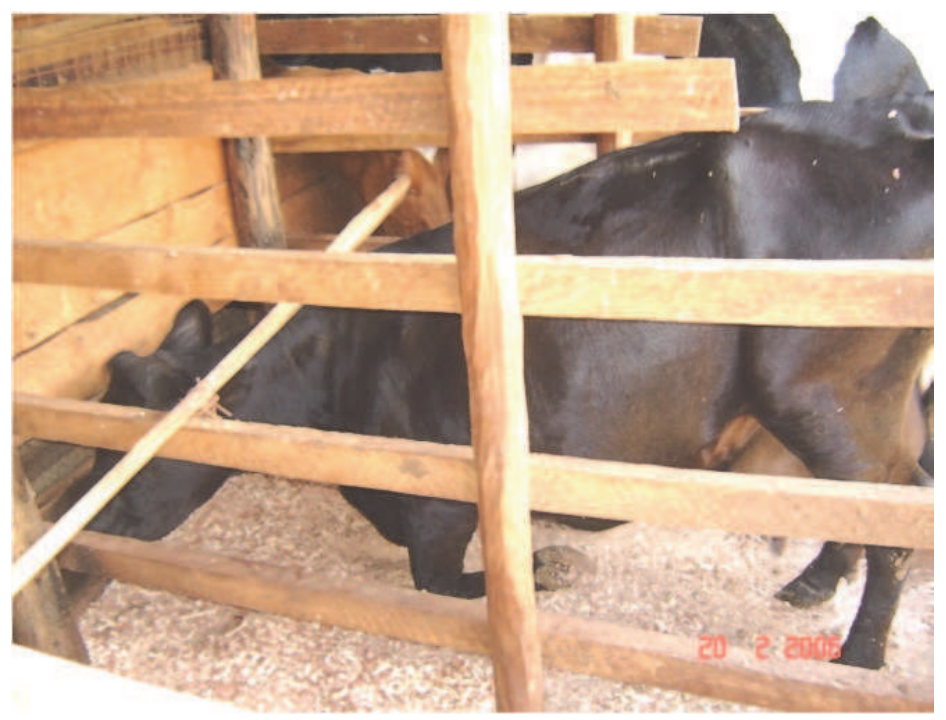

Fig. 18. Inadequate lunging space and bob zone causing difficulties for the cow during standing due to low cross-bar in the cubicle and short length of the cubicle. These were found in some of the zero-grazing units during the study of prevalence and risk factors of claw lesions in the peri-urban areas of Nairobi, Kenya. 


\subsubsection{Feeding regime}

In most of these zero-grazing units, the forage types were mainly mature-wilted or mature non-wilted Napier (Pennisetum purpureum), Rhodes (Cloris gayana) or mixed wild grasses. Only in one of the units were the cows fed on succulent forages. The Napier grass was fed to the cows in chopped small pieces but the Rhodes and wild grasses in whole lengths without chopping. In addition to forages in $16 \%$ of the zero-grazing units, there were supplementations with succulent maize stover or Napier grass silage.

In $81 \%$ of the zero-grazing units, concentrate feeding was regular at every milking time which was at least 2-3 times a day and in some there was additional concentrates given to the cows between the intervals from one milking time to the next. In the remaining $19 \%$ of the units, concentrate feeding was very occasional and inconsistent, being done mostly for one week in a month only when the farmers had money after they were paid for the milk sales of the previous month. The concentrate feeds used were commercially available and were known as "Dairy Meal" (manufactured by Unga Farmcare Limited, Kenya). Information provided by the feed milling firm indicated that the average constituents of the concentrate feed were protein $(15.5 \%$ to $16 \%)$, oils $(6 \%$ to $8 \%)$, fibre (9\% to $10 \%)$ and moisture $(12 \%)$. The concentrates were in fine ground-grains physical form. In the zero-grazing units that provided regular concentrate feeding, each cow was fed with 6-8 kilograms per day. The zero-grazing units that provided concentrates only occasionally were also inconsistent with the quantities provided per cow. No single zero-grazing unit used any standardized concentrate to forage ratios.

Cows in $47 \%$ of the zero-grazing units were fed regularly (once per day) with 50-100 grams of mineral supplements and in $10 \%$ of the units they were fed ad libitum. In $40 \%$ of the units, they were occasionally (at most 1-2 weeks per month) supplemented with 50 grams of minerals per day. In the remaining $3 \%$ of the units, the cows were not given any mineral supplements at all. The mineral supplements given were the locally available commercial mineral mixtures for dairy production such as "Unga High Phosphorus" (Unga Farmcare Limited, Kenya) or "Supper Maclick" (Cooper Kenya limited). The standard mineral supplements used in these zero-grazing units averagely consisted of sodium chloride (18\% to $20 \%$ ), calcium $(16 \%$ to $18 \%)$, phosphorus $(11 \%$ to $12 \%)$, magnesium $(2.5 \%$ to $3 \%)$, iron $(0.5 \%)$, copper $(0.16 \%)$, manganese $(0.4 \%)$, zinc $(0.5 \%)$, sulphur $(0.4 \%)$, cobalt $(0.02 \%)$, iodine $(0.02 \%)$ and selenium $(0.0015 \%)$. The powdered mineral supplements were fed to the cows when mixed with concentrates, but the mineral-lick blocks were provided ad libitum.

\subsubsection{Slurry management and claw trimming}

In $72 \%$ of the zero-grazing units, manure (slurry) was removed from the alleyway at least once per day and in $18 \%$ it was removed more than once per day, while in $10 \%$ of the units it remained for more than one day before being removed (Fig. 19). None of the zero-grazing units had claw trimming programmes and none practiced any claw trimming at all. The farmers were completely ignorant of the need for claw trimming.

\subsection{Association between risk factors and claw disorders}

The animal-level risk factors found to be significantly associated with chronic laminitis were third or higher parities $\left(\chi^{2}=11.57, \mathrm{P}=0.009\right)$ and lactation stage between 90 to 180 days $\left(\chi^{2}\right.$ 
Risk (Predisposing) Factors for Non-Infectious
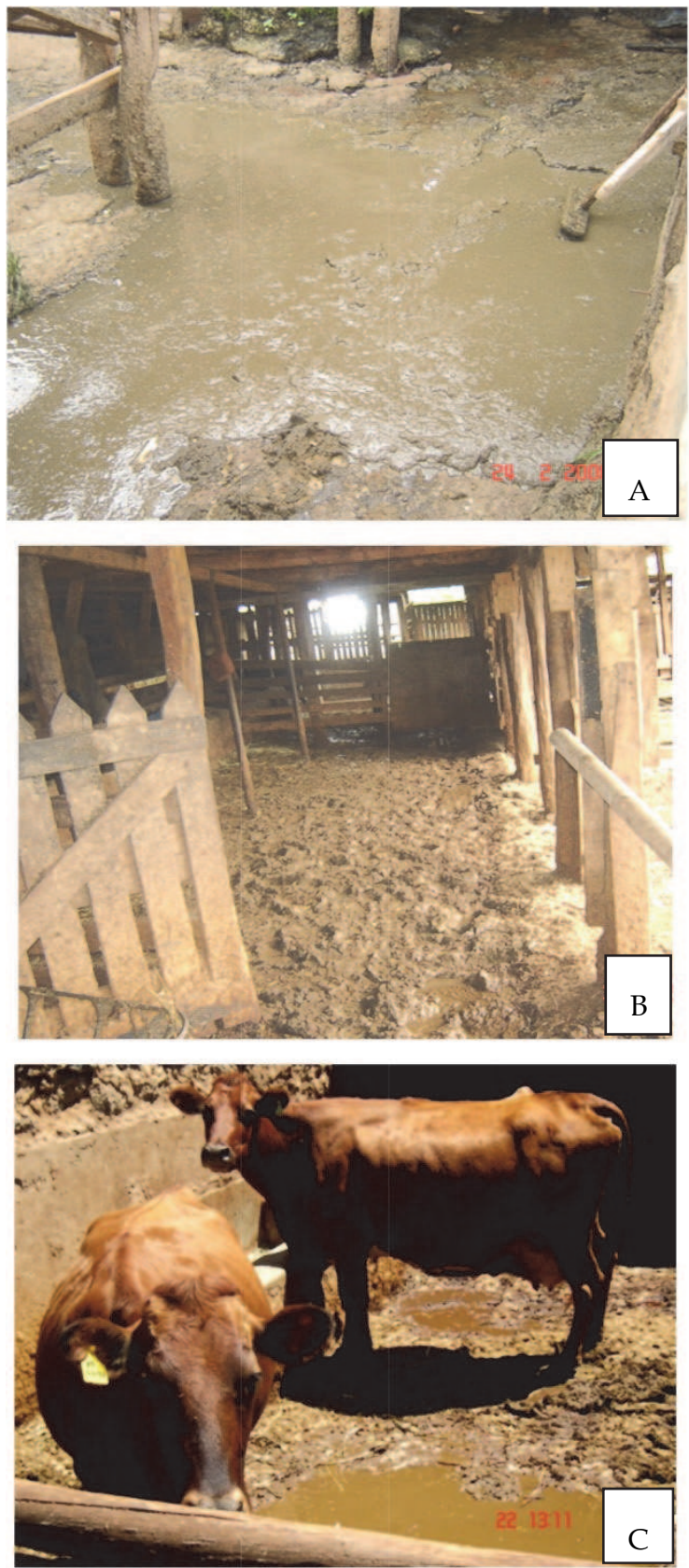

Fig. 19. Three different zero-grazing units A, B, and C in the peri-urban areas of Nairobi, Kenya showing slurry that has been left to accumulate for some days and could predispose the claws of cows to develop lesions. 
$=9.75, \mathrm{P}=0.021)$. But lactation stage between 1 to 90 days was significantly $(\mathrm{X} 2=9.06, \mathrm{P}=$ 0.028 ) associated with subclinical laminitis. Failure to remove manure (more than one day) from the walk-alleys $\left(\mathrm{r}=0.215, \chi^{2}=13.85, \mathrm{P}<0.001\right)$, regular $(2-4$ times per day) concentrate feeding $\left(\mathrm{r}=0.135, \mathrm{x}^{2}=5.45, \mathrm{P}=0.0196\right)$ and lack of or inadequate mineral supplementation $\left(\mathrm{r}=0.172, \mathrm{X}^{2}=8.9, \mathrm{P}=0.0307\right)$ were all found to significantly have unconditional association with subclinical laminitis (Table 2). However stepwise logistic regression analysis (screening interactions of floor types, type of cubicle bedding, manure removal, concentrate feeding, type of forage and mineral supplementation) revealed that the most significant zero-grazing housing-and management-level contributor to the occurrence of subclinical laminitis was regular concentrate feeding ( O.R. $=2.08, \chi^{2}=5.5,95 \%$ C.I: 1.1 to $3.9, P=0.0212$ ).

\begin{tabular}{|l|l|l|l|}
\hline Farm variables & $\chi^{2}$ & r-value & P-value \\
\hline Lack of manure removal & 13.85 & 0.21 & $<0.001$ \\
\hline High concentrate feeding & 5.45 & 0.13 & 0.0196 \\
\hline Lack of mineral supplementation & 8.9 & 0.17 & 0.0307 \\
\hline Floor types & 5.52 & 0.14 & 0.02381 \\
\hline Overstocking (fewer cubicles than cows) & 6.2 & 0.14 & 0.1844 \\
\hline Type of cubicle bedding & 7.2 & 0.15 & 0.5155 \\
\hline Presence of a curb & 0.13 & 0.02 & 0.9361 \\
\hline Fodder type & 3.26 & 0.1 & 0.5151 \\
\hline
\end{tabular}

Table 2. Association of subclinical laminitis with possible risk factors in a study carried out in 300 dairy cows from 32 smallholder zero-grazing units to evaluate digital characteristics of laminitis and related claw lesions in Nairobi and its environs

Zero-grazing housing- and management-level risk factors that had unconditional association with chronic laminitis were revealed by descriptive statistics. These were overstocking (fewer cubicles than the number of cows) $\left(\mathrm{r}=0.36, \chi^{2}=38.87, \mathrm{P}<0.0001\right)$, presence or absence of cubicle bedding $\left(\mathrm{r}=0.312, \chi^{2}=29.13, \mathrm{P}=0.0003\right)$, earthen floor $(\mathrm{r}=$ $\left.0.203, \chi^{2}=12.33, P=0.0151\right)$, presence of a high curb between walk-alley and the cubicles $(\mathrm{r}$ $\left.=0.157, \chi^{2}=7.43, \mathrm{P}=0.0244\right)$, leaving manure (more than one day) in the walk-alleys $(\mathrm{r}=0$. $\left.279, \chi^{2}=23.33, P<0.0001\right)$, regular $\left(2-4\right.$ times per day) feeding with concentrates $\left(r=0.218, \chi^{2}\right.$ $=14.25, \mathrm{P}=0.0002)$, and regular (once per day) mineral supplementation $\left(\mathrm{r}=0.321, \chi^{2}=\right.$ 30.85, P<0.0001) (Table 3).

\begin{tabular}{|l|l|l|l|}
\hline Farm variables & $\chi^{2}$ & r-value & P-value \\
\hline Overstocking (fewer cubicles than cows) & 38.87 & 0.36 & $<0.0001$ \\
\hline Absence of cubicle bedding (bare concrete) & 29.13 & 0.31 & 0.0003 \\
\hline Manure removal (infrequent) & 23.33 & 0.28 & $<0.0001$ \\
\hline Earthen floor type & 12.33 & 0.2 & 0.0151 \\
\hline High concentrate feeding & 14.25 & 0.2 & 0.0002 \\
\hline Lack of mineral supplementation & 30.85 & 0.3 & $<0.0001$ \\
\hline Presence of a curb & 7.43 & 0.16 & 0.0244 \\
\hline
\end{tabular}

Table 3. Association of chronic laminitis with possible risk factors in a study carried out in 300 dairy cows from 32 smallholder zero-grazing units to evaluate digital characteristics of laminitis and related claw lesions in Nairobi and its environs

Furthermore, stepwise logistic regression analysis (testing interactions of all these unconditionally associated factors) pointed out the farm-level factors that most significantly 
contributed to the occurrence of chronic laminitis. These factors were: overstocking (O.R. $=$ 1.7, $\chi^{2}=24.29,95 \%$ C.I $: 1.3$ to 2.2, $\left.\mathrm{P}=0.0002\right)$, earthen floor (O.R. $=1.5, \chi^{2}=8.98,95 \%$ C.I: 1.2 to $2.0, \mathrm{P}=0.0006)$, and presence of a curb between walk-alleys and the cubicles (O.R. $=1.5$, $X^{2}=5.06,95 \%$ C.I $: 1.1$ to $2.2, P=0.0262$ ).

The data and statistical analyses indicated that regular (2-4 times per day) concentrate feeding seemed to significantly $(\beta$-estimate $=2.187$, s.e. $=0.814, \mathrm{P}=0.007)$ enhance occurrence of sole bruising. Conversely, earthen floor (bare soil) $(\beta$-estimate $=-1.796$, s.e. $=$ $0.835, \mathrm{P}<0.001$ ) and regular (at least once per day) mineral supplementation $(\beta$-estimate $=$ 4.59 , s.e. $=1.50, \mathrm{P}=0.002$ ) seemed to significantly protect against occurrence of sole bruising. The study also indicated that removal of manure more than once per day significantly $(\beta-$ estimate $=-3.58$, s.e. $=1.01, \mathrm{P}<0.001)$ protected the claws against occurrence of white line separation, while regular (at least once per day) mineral supplementation was found to significantly ( $\beta$-estimate $=-4.07$, s.e. $=2.05, \mathrm{P}=0.048$ ) reduce the frequency of its occurrence. However, regular concentrate feeding seemed to significantly $(\beta$-estimate $=3.69$, s.e. $=1.24$, $\mathrm{P}=0.003$ ) enhance occurrence of white line separation

Furthermore, good concrete floors (non-slip with no ground defects) seemed significantly ( $\beta$-estimate $=-1.969$, s.e. $=0.597, \mathrm{P}<0.001)$ protective against occurrence of heel erosion . There were no statistically significant associations found between the rest of the zerograzing housing-and management-level factors, and the claw disorders. Among the cows with chronic laminitis $89 \%$ were zero-grazed and only $11 \%$ were pasture-grazed. However, this difference was found to be statistically significant $\left(\chi^{2}=11.0, P<0.001\right)$

\section{Discussion}

The strength of this paper is elaborated by the important variations in housing designs, nutritional regimes and management protocol in these smallholder zero-grazing dairy units. The dairy production protocol in these units is so varied to the extent that they can further be subdivided into subunits. It is of paramount importance to note that the prevalent claw disorders affecting cows in these zero-grazing units are non-infective in nature and associated with laminitis syndrome. It is also worth noting that the lesions with high prevalence are mainly non-clinical with the highest proportion being subclinical laminitis. This could be attributed to presence of low-grade but persistent predisposing factors existing in these zero-grazing units that cause insidious claw damage eventually leading to clinical manifestations at an advanced stage that may already have caused irreversible changes in the claws particularly with effects of laminitis (Belge \& Bakir, 2005; Nocek, 1997). The significance of high prevalence of subclinical laminitis in these zero-grazing production systems cannot be underrated since it serves as a major contributor to development of other more severe clinical claw lesions with far reaching effects such as sole bruising, heel erosion, white line separation, double soles and eventually chronic laminitis if early remedial measures are not instituted. Such outcomes have been reported previously (Nocek, 1997). A retrospective study carried out on the cases of cattle referred from the same area to the University of Nairobi Large Animal Hospital in the earlier years indicated that previously there was high prevalence of infective claw lesions and negligibly low prevalence of laminitis and associated lesions (Nguhiu-Mwangi, et al., 2008). The pattern of occurrence of claw lesions in the same area has remarkably shifted to high prevalence of non-infective 
laminitis related lesions since the adoption of confinement of cattle in zero-grazing housing units, whose floors are concreted hence improving on hygiene (Nguhiu-Mwangi, et al., 2009). With the likelihood of improved cleanliness and hygiene of the modern type of cattle houses, the prevalence of infective claw lesions is bound to continually decline.

The importance of the claw lesions prevalent in the cows in these zero-grazing units is that they mainly affect the horn of the claw. When the horn is affected, the claws become vulnerable to many types of insults because it interferes with the protection of the interior parts of the claws. The effects on the horn are due to the fact that in these lesions there underlies the laminitis syndrome as the cause or sequel of the lesions. During this laminitis syndrome, the damaged corium produces poor quality horn that is softer than normal as previously reported (Baggott \& Russell, 1981; Nocek, 1997; Weaver, 1979). This explains why the whitish soft crumbling horn was seen in some claws with chronic laminitis in this study. The softer low integrity horn of the sole and the heel predisposes these sites to bruising and erosion, hence the high prevalence of sole bruising and heel erosion. Since the horn quality is poorer in chronic laminitis, sole bruising and heel erosion become more severe during that phase of laminitis. The softened horn easily undergoes bacterial erosion and necrosis (Nocek, 1997) particularly when combined with other physical factors that cause horn softening such as accumulation of slurry on the floor of the cow house (Baggott \& Russell, 1981). Sole bruising and heel erosion were found to be deeper and affecting more weight-bearing zones of the claw when the corium was more damaged. When these two lesions are spread more widely on the weight-bearing surface of the claw, it also means they involve the horn more deeply. This makes the prognosis poor because trimming-off the eroded horn leaves very thin layer of normal horn (Nguhiu-Mwangi, 2007) through which external insults easily traverse and damage the underlying corium further. However, when sole bruising and heel erosion are diagnosed early, the necrotic eroded horn can effectively be trimmed-off and the claws dipped in or sprayed with antimicrobial chemicals with either $5 \%$ formalin solution or $5-7 \%$ copper sulphate solution.

Alterations in the shape of the claws in chronic laminitis has been reported previously (Greenough, 1987; Nocek, 1997) and is attributed to disruption in growth of keratinized horn (Nocek, 1997). This shape alterations associated with chronic laminitis are severe, irreversible and render reshaping of the claw difficult; hence they give chronic laminitis poor prognosis (Baggott \& Russell, 1981; Nguhiu-Mwangi et al., 2008). This explains why attempts made to manage deformity conditions by trimming claws of the affected cows during this study, proved to be of little benefit. Therefore, the finding of irregularly shaped (unusual flattening, widening, concaving and rippling of the dorsal wall) claws in chronic laminitis is an indication of poor prognosis (Nguhiu-Mwangi et al., 2008) and attempts to manage them by trimming are therefore only palliative and short-lived. Ignorance and negligence of claw trimming practices in the zero-grazing units that were included in this study have been major cause and an aggravating factor in the progression of claw disorders to chronic stages. This contributes to long-term claw damage and worsens the prognoses (Nguhiu-Mwangi, 2007). It has been shown that trimming of hooves leads to lower locomotion scores and reduced clinical lameness (Manson \& Leaver, 1988). When claws are excessively overgrown, weight-bearing is shifted towards the proximal parts near the heel bulb. These parts have softer and weaker horn that inadequately protects the underlying corium (Collins-née Hedges et al., 2004). Excessive claw overgrowth then leads to undue 
mechanical pressure on the solar corium due to excessive weight-bearing on the pedal bone and inadequate support of the corium by the horny capsule at the sole especially following thinning of the horn of the sole in laminitis (Baggott \& Russell, 1981; Toussaint-Raven, 1973). Trimming tends to return the claw to near normal weight-bearing even at chronic stages of regular overgrowth (Weaver, 1993). However, when overgrowth is combined with chronic laminitis, the pedal bone undergoes irreversible alteration in its configuration within the claw capsule (Bargai et al., 1989; Greenough et al., 1990) and this result in poor prognosis.

It is prudent to conclude that regular examination is the most important way of ensuring good claw health. The most practical way to regularly observe the claws is during the milking times. Examination of the claws cannot be conclusive without trimming at least the horn of the sole. This is necessitated by the fact that lesions underneath the horn of the claws are not discernible externally until exposed by trimming (Nguhiu-Mwangi, 2007; Nocek, 1997). Such routine examination will help to recognize and manage claw disorders in the early stages before they progress to unmanageable chronic stages in which the claws are irreversibly damaged. Furthermore, the corium is the tissue that determines the health of the claw. It should therefore be protected from unnecessary insults by ensuring that it is adequately covered by sufficient claw capsule (hoof) thickness whose hardness is maintained by avoiding wet underfoot environment and that distribution of weightbearing is correctly maintained according to the relative hardness of various parts of the claw (Berry, 1999).

Although regular concentrate feeding in these farms for each cow meant 2 to 4 times per day, nevertheless the feeding frequencies and amounts in each farm were inconsistent and this was similar for mineral supplementation. The results of this study indicated that most of the claw lesions encountered were related to laminitis in nature (Belge \& Bakir, 2005; Nocek, 1997) and this could highly suggest the presence of predisposing risk factors in the smallholder zero-grazing units that were studied. Lactation period between 1 to 90 days is the time that subclinical laminitis is most prevalent. This could be attributed to the continuing effects of the transitional period of feeding with high energy concentrates that cause subacute ruminal acidosis and release of vasoactive agents, subsequently triggering laminitic processes (Donovan et al., 2004; Vermunt, 2004). The laminitic processes are further aggravated by the stress of heavy milk production during the first 90 to 120 days post-calving (Rowlands et al., 1985). Gradual progression of subclinical laminitis lesions culminates into chronic laminitis (Nocek, 1997), which could explain the reason for association between the later stages of lactation and chronic laminitis. The association between 3rd or higher parities with chronic laminitis agrees with previous findings by Sogstad et al. (2005) that most lameness is generally associated with third or higher parities. The habit of leaving manure in the walk-alleys for more than one day enhanced development of both subclinical and chronic laminitis. This could be attributed to persistent wetness that causes excessive softening of the claw-horn making it easily susceptible to horn-lesions. With softer solear horn, pressure insult from the ground is easily transmitted to the underlying solear corium which then becomes traumatized, resulting in laminitis. These findings agree with previous reports (Borderas et al., 2004; Vermunt, 2004).

The association of high concentrates feeding with subclinical and chronic laminitis as well as with sole bruising and white line separation is attributed to SARA and production of 
vasoactive substances. This initially triggers development of subclinical laminitis as has been reported previously (Cook et al., 2004; Vermunt, 2004). Subclinical laminitis then predisposes the cow to other claw lesions (Nocek, 1997). Failure or inadequate supplementation of the cows with mineral mixtures was associated with enhanced development of subclinical and chronic laminitis as well as white line separation. This finding conforms to the reports stating that trace-minerals reduce claw lesion scores (Tomlinson et al., 2004) and biotin supplementation reduces macro-cracks in the claws (Higuchi \& Nagahata, 2001). The positive association between overstocking and chronic laminitis may be attributed to the long hours of standing because of fewer cubicles. Standing for long periods causes prolonged pressure injury to the solear corium, thus being an exacerbating factor to the development of claw lesions as reported previously (Leonard et al., 1994). Further to this, the presence of a high curb between the walk-alley and the cubicles was found to be one of the main factors enhancing occurrence of chronic laminitis. This factor may possibly cause additional stress to the claws as the cow enters or disembarks from the cubicle, as has been suggested by others (Leonard et al., 1994; Philipot et al., 1994). Eventually it contributes to compromise of the entire phenomenon of "cow comfort" and some cows prefer standing on the free alleys to occupying the cubicles. Standing for long periods in the free walk-alleys causes further stress to the corium.

The results of this study also found that housing cows on earthen (bare soil) floors was an important risk factor for development of chronic laminitis. This is possibly due to the fact that such floors have soft (yielding) surfaces which tend to promote overgrowth of the claws for lack of constant hoof-wear (Rhebun \& Pearson, 1982). Claw overgrowth and change in its angle result in redistribution of weight-bearing that subsequently overloads specific zones of the claw particularly during locomotion (Van der Tol et al., 2003). Consequently, these effects predispose the affected claws to development of laminitis and other claw lesions (Neveux et al., 2006; Sagues, 2002). However, earthen floors were found to be protective against occurrence of sole bruising. This could be attributed to the floor being soft, yielding and non-abrasive which closely relates to a previous report by Somers et al. (2003) stating that cows raised on yielding straw-yard surfaces were found to have very low prevalence of claw disorders. Chronic laminitis is the only claw disorder that showed a significant difference between cows in zero-grazed and in pasture-grazed farms with higher prevalence in zero-grazed cows. The hard concrete surface that was more common in the zero-grazed farms, probably combined with regular concentrate feeding, could have contributed to the difference in the prevalence rates of chronic laminitis between zerograzed and pasture grazed farms (Bergsten, 1994; Somers et al., 2003; Vokey et al., 2001).

Absence of cubicle bedding and presence of bare concrete in the cubicles was found to be associated with occurrence of chronic laminitis. Some of the cubicles were narrow in such a way that cows remained in a standing posture even within the cubicles. This act of standing in the cubicles further prolongs the cumulative period of stress exerted on the claws while on concrete. The consequence of this stress is the increased incidence of claw lesions, particularly laminitis (Bergsten \& Herlin, 1996; Somers et al., 2003). Good concrete (non-slip, without defects or loose stone pebbles) was protective against heel erosion probably due to the absence of traumatic edges. The non-slip nature of the floor would also prevent abrasive trauma on both the heel and sole. 


\section{Conclusion}

The smallholder zero-grazing dairy units in the peri-urban areas of Nairobi, Kenya have uniquely wide variations in their production systems with respect to housing designs, nutritional regime and management protocol. From the statistical associations in this study, it can be concluded that the cow-level factors that strongly contribute to the development of claw lesions are 3rd or higher parities and being in the lactation period between 1 to 90 days. The farm level factors that strongly enhance claw lesion development are frequent high concentrate feeding, lack of regular mineral supplementation, both concrete and earthen floors, overstocking, the presence of a curb between walk-alley and cubicles, and leaving manure in the walk-alley for a long time. These associations are supported strongly by statistics that indicate the direction and strength of the relationship. It can also be concluded that non-infective claw disorders in dairy cows particularly the disorders related to laminitis are insidious in nature, which gradually but progressively damage the integrity of the claw. The subclinical occurrence of these disorders makes them subtle and careful early diagnosis so that remedial measures can be instituted early before these irreversible damages have occurred is essential. The fact that a cow does not show signs of lameness does not necessarily imply her claws are sound, but only calls for further careful scrutiny. Claw trimming is one of the major ways of discerning these underlying claw disorders at the subclinical phase.

\section{Future research}

Due to the wide variations in the smallholder production units in the study area, there is a need to carry out a controlled experimental study to further elucidate these risk factors. A comparative study should also be carried out in Kenya to establish if similar risk factors exist in the large scale better managed farms. Each of the risk factors incriminated in the current study needs individual experimental evaluation.

\section{Acknowledgements}

We are grateful to the Deans Committee, University of Nairobi, Kenya for providing a proportion of financial support to carry out the study.

\section{References}

Baggott, D.G. \& Russell, A.M. (1981): Lameness in cattle. British Veterinary Journal vol.137, pp 113-132

Bargai, U, Pharr, J.W.\& Morgan, J.D. (1989) radiographic changes in chronic laminitis Proceedings of the $8^{\text {th }}$ International Symposium on Disorders of Ruminant Digit and International Conference on Bovine Lameness. Saskatoon, Saskachewan, and Banff, Alberta, Canada. pp 207

Belge, A. \& Bakir, B. (2005). Subclinical laminitis in dairy cattle: 205 selected cases. Turkish Journal of Veterinary and Animal Science, vol. 29, pp 9-15

Bergsten, C. (1994). Haemorrhages of the sole horn of dairy cows as a retrospective indicator of laminitis: an epidemiological study. Acta Veterinaria Scandinavica. Vol.35, pp 5566 
Bergsten, C. \& Herlin, A.H. (1996). Sole haemorrhages and heel horn erosion in dairy cows: the influence of housing on their prevalence and severity. Acta Veterinaria Scandinavica vol37, pp395-408

Berry, S.L. (1999). Hoof health. Proceedings of the Western Dairy Management Conference.. Las Vegas, Nevada, April 8-10, 1999, pp 13-17

Borderas, T.F., Pawluczukk, B., de Passille, A.M. \& Rushen, J. (2004). Claw hardness of dairy cows: relationship to water content and claw lesions. Journal of Dairy Science, vol. 87,pp 2085-2093.

Clarkson, M.J., Downham, D.Y., Faull, W.B., Murray. R.D., Russell, W.B., Sutherst, J. \& Ward, W.R. (1996). Incidence and prevalence of lameness in dairy cattle. Veterinary Record, vol. 138, pp 563-567

Collins-née Hedges, V.J., Green, L.E., Blowey, R.W., Packington, A.J. \& Bonser, R.H.C. (2004). Testing white line strength in the dairy cows. Journal of Dairy Science, vol.87, pp 2874-2880

Cook, N.B., Nordlund, K.V. \& Oetzel, G.R. (2004). Environmental influences on claw horn lesions associated with laminitis and subacute ruminal acidosis in dairy cows. Journal of Dairy Science, Vol. 87, pp E36-E46

Donovan, G.A., Risco, C.A., DeChant Temple, G.M., Tran, T.Q. \& van Horn, H.H. (2004). Influence of transition diets on occurrence of subclinical laminitis in Holstein dairy cows. Journal of Dairy Science, vol. 87, pp 73-84

Enting, H. D., Kooij, A. A., Dijkhiuzen, R. B. M., Huirne, R. B. M. \& Noordhuizen-Stassen, E. N. (1997). Economic losses due to clinical lameness in dairy cattle. Livestock Production Science, vol 49, pp 259-267

Garbarino, E.J., Hernandez, J.A., Shearer, J.K., Risco, C.A. \& Thatcher, W.W. (2004). Effects of lameness on ovarian activity in postpartum Holstein cows. Journal of Dairy Science vol. 87, pp 4123-4131

Gitau, T. (1994). Bovine lameness in small-scale dairy farms in Kikuyu division, Kiambu district, Kenya. Msc. Thesis, University of Nairobi, Kenya

Greenough, P. R. (1987). An illustrated compendium of bovine lameness. Part 1. Modern Veterinary Practice, vol. 68, pp 6-9

Greenough, P.R., Vermunt, J.J., McKinnon, J.J., Fathy, F.A., Berg, P.A. \& Cohen, R.D.H. (1990). Laminitis-like changes in the claws of feedlot cattle. Canadian Veterinary Journal, vol. 31, pp 202-208

Greenough, P.R. \& Vermunt, J.J. (1991). Evaluation of subclinical laminitis in a dairy herd and observations on associated nutritional and management factors. Veterinary Record, vol. 128, pp 11-17

Hernandez, J.A., Garbarino, E.J., Shearer, J.K., Risco, C.A. \& Thatcher, W.W. (2005). Comparison of the calving-to-conception interval in dairy cows with different degrees of lameness during the prebreeding postpartum period. Journal of. American Veterinary Medical Association, vol. 227, pp1284-1291

Higuchi, H. \& Nagahata, H. (2001). Relationship between serum biotin concentration and moisture content of the sole horn in cows with clinical laminitis or sound claws. Veterinary Record, vol.148, pp 209-210

Kossaibati, M. A. \& Esslemont, R. J. (1997). The cost of production diseases in dairy herds in England. Veterinary Journal, vol.154, pp 41-51

Leonard, F.C., O'Connell, J.M. \& O'Farrell, K.J. (1994). Effect of different housing conditions on behaviour and foot lesions in Friesian heifers. Veterinary Record, vol.134, pp 490494 
Manske, T., Hultgren, J. \& Bergsten, C. (2002). The effect of claw trimming on the hoof health of Swedish dairy cattle. Preventive Veterinary Medicine, vol. 54, pp 113-129

Manson, F.J., \& Leaver, J.D. (1988). The Influence of dietary protein intake and of hoof trimming on lameness in dairy cattle. Animal Production,vol. 47, pp 191-199

Mbithi, P.M.F., Mbiuki, S.M., Nguhiu-Mwangi, J. \& Kihurani, D.O. (1991). Non-fracture lameness in cattle: A retrospective study. Bulletin of Animal Health and Production in Africa, vol. 39, pp 307-309

Melendez, P., Bartolome, J., Archbald, L.F. \& Donovan, A. (2003). The association between lameness, ovarian cysts and fertility in lactating dairy cows. Theriogenology, vol.59, pp 927-937

Mutugi, J.J. (2004). Various livestock production systems. Workshop Proceedings on Cattle Production in Kenya-Strategies for Research Planning and Implementation, KARI Headquarters, Kabete, Kenya, December 2003. pp 3-35

Neveux, S., Weary, D.M., Rushen, J.;, von Keyserlingk, M.A.G. \& de Passillé, A.M. (2006). Hoof discomfort changes how dairy cattle distribute their body weight. Journal of Dairy Science, vol. 89, pp 2503-2509

Nguhiu-Mwangi, J. (2007). Characteristics of laminitis and associated claw lesions in dairy cows in Nairobi and its environs. PhD thesis, University of Nairobi, Kenya.

Nguhiu-Mwangi, J., Mbithi, P.M.F., Wabacha, J.K., Mbuthia, P.G. (2007). Prevalence of sole haemorrhages and its correlation with subclinical and chronic laminitis in dairy cow. Bulletin of Animal Health and Production in Africa, vol. 55, pp 232-242

Nguhiu-Mwangi, J., Mbithi, P.M.F., Wabacha, J.K., Mbuthia, P.G. (2008). Factors associated with the occurrence of claw disorders in dairy cows under smallholder production systems in urban and peri-urban areas of Nairobi, Kenya. Veterinarski Arhiv, vol. 78, No. 4, pp 343-355, ISSN 0372-5480

Nguhiu-Mwangi, J., Mbithi, P.M.F., Wabacha, J.K., Mbuthia, P.G. (2009). Prevalence of laminitis and the patterns of claw lesions in dairy cows in Nairobi and the periurban districts. Bulletin of Animal Health and Production in Africa, Vol. 57, pp 199-208.

Nocek, J.E. (1997): Bovine acidosis: implications on laminitis. Journal of Dairy Science vol 80: 1005-1028.

Offer, J.E., McNulty, D. \& Logue, D.N. (2000). Observations of lameness, hoof conformation and development of lesions in dairy cattle over four lactations. Veterinary Record, vol. 147, pp 105-109

Philipot, J.M., Pluvinage, P., Cimarosti, I., Sulpice, P. \& Bulgnard, F. (1994). Risk factors of dairy cow lameness associated with housing conditions. Veterinary Research, vol. 25, pp 244-248

Rhebun, W.C. \& Pearson, E.G. (1982). Clinical management of bovine foot problems. Journal of American Veterinary Medical Association, vol. 181, pp 572-579

Rowlands, G.J., Russell, A.M. \& Williams, L.A. (1985). Effects of stage of lactation, month, age, and heart girth on lameness in dairy cattle. Veterinary Record, vol.117, pp 576580

Sagues, A.G. (2002). The biomechanics of weight bearing and its significance with lameness. Proceedings of the $12^{\text {th }}$ International Symposium on Lameness in Ruminants, Orlando, Florida, U.S.A., 9th-13th January, 2002, pp 117-121

Smilie, R.H., Hoblet, K.H., Eastridge, M.L., Weiss, W.P., Schnitkey, G.L. \& Moeschberger, M.L. (1991). Subclinical laminitis in dairy cows: use of severity of hoof lesions to rank and evaluate herds. Veterinary Record, vol.144, pp 17-21 
Sogstad, A.M., Fjeldaas, T. \& Østeras, O. (2005). Lameness and claw lesions of the Norwegian red dairy cattle housed in free-stalls in relation to environment, parity and stage of lactation. Acta Veterinaria Scandinavica, vol. 46, pp 203-217

Sogstad, A.M., Østeras, O. \& Fjeldaas, T. (2006). Bovine claw and limb disorders related to reproductive performance and production diseases. Journal of Dairy Science, vol.89, pp 2519-2528

Somers, J.G.C.J., Frankena, K., Noordhuizen-Stassen, E.N. \& Metz, J.H.M. (2003). Prevalence of claw disorders in Dutch dairy cows exposed to several floor systems. Journal of Dairy Science, vol.86, pp 2082-2093

Somers, J.G.C.J., Schouten, W.G.P., Frankena, K., Noordhuizen-Stassen, E.N. \& Metz, J.H.M. (2005). Development of claw traits and claw lesions in dairy cows kept on different floor systems. Journal of Dairy Science, vol. 88, pp 110-120

Sprecher, D.J.; Hostetler, D.E. and Kaneene, J. B. (1997). A lameness scoring system that uses posture and gait to predict dairy cattle reproductive performance. Theriogenology, vol. 47, pp 1179-1187

Toussaint-Raven, E. (1973): Lameness in cattle and foot care. Netherlands Journal of Veterinary Science, vol.5, pp 105-111

Van der Tol P.P.J., Metz, J.M.H., Noordhuizen-Stassen, E.N., Back, W.; Braam, C.R. \& Weijs, W.A. (2003). The vertical ground reaction force and the distribution on the claws of dairy cows while walking on a flat substrate. Journal of Dairy Science, vol. 86, pp 2875-2883

Vermunt, J. (2004). Herd lameness: a review, major causal factors, and guidelines for prevention and control. Proceedings of the $13^{\text {th }}$ International symposium and $5^{\text {th }}$ Conference on Lameness in Ruminants, Maribor, Slovenija, 11 th $-15^{\text {th }}$ February, 2004, pp 1-15.

Vokey, F.J., Guard, C.L., Erb, H.N.\& Galton, D.M. (2001). Effects of alley and stall surfaces on indices of claw and leg health in dairy cattle housed in a free-stall barn. Journal of Dairy Science, vol. 84, pp 2686-2699

Wanyoike, M.M.\& Wahome, R.G. (2004). Small-Scale farming systems. Workshop Proceedings, on Cattle Production in Kenya-Strategies for Research Planning and Implementation, KARI Head quarters, Kabete, Kenya,. December. 2003, pp 87-133

Weaver, A.D. (1993). Aseptic laminitis of cattle, Interdigital and Digital dermatitis, Interdigital Phlegmon (interdigital necrobacillosis). Current Veterinary Therapy 3. Food Animal Practice, W.B. Saunders, Philadelphia. pp 867-870.

Weaver, A.D. (2000). Lameness. The health of Dairy Cattle, Blackwell Science, Oxford, U.K. pp 149-202. 


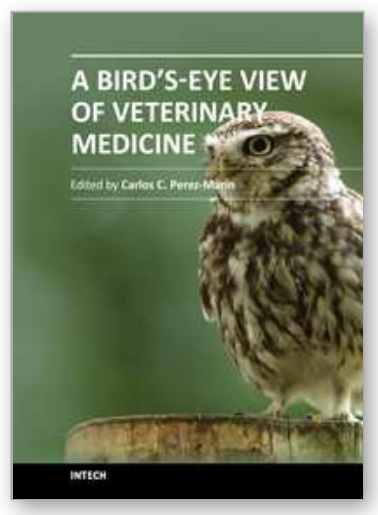

\author{
A Bird's-Eye View of Veterinary Medicine \\ Edited by Dr. Carlos C. Perez-Marin
}

ISBN 978-953-51-0031-7

Hard cover, 626 pages

Publisher InTech

Published online 22, February, 2012

Published in print edition February, 2012

Veterinary medicine is advancing at a very rapid pace, particularly given the breadth of the discipline. This book examines new developments covering a wide range of issues from health and welfare in livestock, pets, and wild animals to public health supervision and biomedical research. As well as containing reviews offering fresh insight into specific issues, this book includes a selection of scientific articles which help to chart the advance of this science. The book is divided into several sections. The opening chapters cover the veterinary profession and veterinary science in general, while later chapters look at specific aspects of applied veterinary medicine in pets and in livestock. Finally, research papers are grouped by specialisms with a view to exploring progress in areas such as organ transplantation, therapeutic use of natural substances, and the use of new diagnostic techniques for disease control. This book was produced during World Veterinary Year 2011, which marked the 250th anniversary of the veterinary profession. It provides a fittingly concise and enjoyable overview of the whole science of veterinary medicine.

\title{
How to reference
}

In order to correctly reference this scholarly work, feel free to copy and paste the following:

J. Nguhiu-Mwangi, P.M.F. Mbithi, J.K. Wabacha and P.G Mbuthia (2012). Risk (Predisposing) Factors for NonInfectious Claw Disorders in Dairy Cows Under Varying Zero-Grazing Systems, A Bird's-Eye View of Veterinary Medicine, Dr. Carlos C. Perez-Marin (Ed.), ISBN: 978-953-51-0031-7, InTech, Available from: http://www.intechopen.com/books/a-bird-s-eye-view-of-veterinary-medicine/risk-predisposing-factors-for-noninfectious-claw-disorders-in-dairy-cows-under-varying-zero-grazing

\section{INTECH}

open science | open minds

\section{InTech Europe}

University Campus STeP Ri

Slavka Krautzeka 83/A

51000 Rijeka, Croatia

Phone: +385 (51) 770447

Fax: +385 (51) 686166

www.intechopen.com

\section{InTech China}

Unit 405, Office Block, Hotel Equatorial Shanghai

No.65, Yan An Road (West), Shanghai, 200040, China 中国上海市延安西路65号上海国际贵都大饭店办公楼 405 单元

Phone: +86-21-62489820

Fax: $+86-21-62489821$ 
(C) 2012 The Author(s). Licensee IntechOpen. This is an open access article distributed under the terms of the Creative Commons Attribution 3.0 License, which permits unrestricted use, distribution, and reproduction in any medium, provided the original work is properly cited. 